Article

\title{
Rheological, Microstructural and Thermal Properties of Magnetic Poly(Ethylene Oxide)/Iron Oxide Nanocomposite Hydrogels Synthesized Using a One-Step Gamma-Irradiation Method
}

\author{
Ivan Marić ${ }^{1}$, Nataša Šijaković Vujičić ${ }^{2}{ }^{\circ}$, Anđela Pustak ${ }^{1}$, Marijan Gotić ${ }^{3}$, Goran Štefanić ${ }^{3}$, \\ Jean-Marc Grenèche ${ }^{4}\left(\mathbb{D}\right.$, Goran Dražić ${ }^{5}$ and Tanja Jurkin ${ }^{1, *}$ \\ 1 Radiation Chemistry and Dosimetry Laboratory, Division of Materials Chemistry, Ruđer Bošković Institute, \\ Bijenička Cesta 54, 10000 Zagreb, Croatia; imaric@irb.hr (I.M.); apustak@irb.hr (A.P.) \\ 2 Laboratory for Supramolecular Chemistry, Division of Organic Chemistry and Biochemistry, \\ Ruđer Bošković Institute, Bijenička Cesta 54, 10000 Zagreb, Croatia; Natasa.Sijakovic-Vujicic@irb.hr \\ 3 Laboratory for Molecular Physics and Synthesis of New Materials, Division of Materials Physics, \\ Ruđer Bošković Institute, Bijenička Cesta 54, 10000 Zagreb, Croatia; gotic@irb.hr (M.G.); \\ Goran.Stefanic@irb.hr (G.Š.) \\ 4 Institut des Molécules et Matériaux du Mans (IMMM UMR CNRS 6283), Le Mans Université, \\ Avenue Olivier Messiaen, F-72085 Le Mans CEDEX 9, France; jean-marc.greneche@univ-lemans.fr \\ 5 Department of Materials Chemistry, National Institute of Chemistry, Hajdrihova 19, \\ SI-1001 Ljubljana, Slovenia; goran.drazic@ki.si \\ * Correspondence: tjurkin@irb.hr; Tel.: +385-1-4571-255
}

Received: 31 July 2020; Accepted: 10 September 2020; Published: 12 September 2020

\begin{abstract}
Magnetic polymer gels are a new promising class of nanocomposite gels. In this work, magnetic PEO/iron oxide nanocomposite hydrogels were synthesized using the one-step $\gamma$-irradiation method starting from poly(ethylene oxide) (PEO) and iron(III) precursor alkaline aqueous suspensions followed by simultaneous crosslinking of PEO chains and reduction of $\mathrm{Fe}(\mathrm{III})$ precursor. $\gamma$-irradiation dose and concentrations of $\mathrm{Fe}^{3+}, 2$-propanol and PEO in the initial suspensions were varied and optimized. With 2-propanol and at high doses magnetic gels with embedded magnetite nanoparticles were obtained, as confirmed by XRD, SEM and Mössbauer spectrometry. The quantitative determination of $\gamma$-irradiation generated $\mathrm{Fe}^{2+}$ was performed using the 1,10-phenanthroline method. The maximal $\mathrm{Fe}^{2+}$ molar fraction of 0.55 was achieved at $300 \mathrm{kGy}, \mathrm{pH}=12$ and initial $5 \%$ of $\mathrm{Fe}^{3+}$. The DSC and rheological measurements confirmed the formation of a well-structured network. The thermal and rheological properties of gels depended on the dose, PEO concentration and initial $\mathrm{Fe}^{3+}$ content (amount of nanoparticles synthesized inside gels). More amorphous and stronger gels were formed at higher dose and higher nanoparticle content. The properties of synthesized gels were determined by the presence of magnetic iron oxide nanoparticles, which acted as reinforcing agents and additional crosslinkers of PEO chains thus facilitating the one-step gel formation.
\end{abstract}

Keywords: magnetic hydrogel; gamma-irradiation; poly(ethylene oxide); magnetite; rheological properties; thermal properties; ${ }^{57} \mathrm{Fe}$ Mössbauer spectrometry; XRD; SEM; Fe(II) determination

\section{Introduction}

Magnetic polymer gels (ferrogels) are a new and promising class of nanocomposite hydrogels that have the potential to be used as effective absorbents of toxic ions in water, protein immobilization, separation, in soft actuators such as artificial muscles, in tissue engineering, drug delivery and hyperthermia applications [1-7]. Ferrogels combine the elastic properties and the defined structure 
of gels with the magnetic properties of magnetic nanoparticles (usually magnetite or maghemite) and respond quickly to the external magnetic field. Apart from their unique magnetic properties, nanocomposite gel scaffolds with embedded magnetite/maghemite nanoparticles have exhibited superior mechanical, rheological and electrical properties compared to scaffold gels without nanoparticle reinforcement, better biocompatibility, low cytotoxicity, and demonstrated antibacterial properties [1-4]. Furthermore, iron oxide nanoparticles have been shown to promote osteogenic differentiation of stem cells [8-10] and can provide the transduction of the dynamic mechanical stimulation required for bone formation [11].

Nanocomposite gels can be synthesized by a variety of methods, including the radiolytic method. $\gamma$-irradiation (radiolytic method) has the advantage of a pure and homogeneous initiation of the polymer crosslinking reaction and reduction of metal cations, as well as the sterility of the final product. Typically, nanocomposite gels are synthesized by two-step methods: (i) $\gamma$-irradiation induced crosslinking of the polymer in solution in the presence of pre-prepared nanoparticles (NPs) [12,13] or (ii) in situ $\gamma$-irradiation synthesis of nanoparticles within the already prepared polymer gel [14-17]. Of particular interest is the one-step $\gamma$-irradiation synthesis of nanocomposite gels. However, the one-step synthesis has the advantage of simultaneous crosslinking of polymer chains with the formation of network and reduction of metal salts and the formation of NPs. The one-step synthesis is faster and simpler and results in a small NPs size and narrow size distribution as well as homogeneous distribution of NPs throughout the polymer matrix. On the other hand, the one-step synthesis of nanocomposite gels has been poorly studied, as it is difficult to find favorable conditions for both nanoparticle synthesis and polymer crosslinking.

The $\gamma$-irradiation method is highly suitable for the synthesis of NPs of controlled size and shape in a solution and in heterogeneous media such as hydrogels. It is also suitable for forming the three-dimensional polymer network. However, the studies are mostly oriented toward the synthesis of metal NPs and gels containing metal NPs. The radiolytic synthesis of iron oxide nanoparticles and nanocomposite gels is rarely studied [18-28]. One of the reasons for this is a very complex iron oxide chemistry, which generates numerous iron oxide and oxyhydroxide polymorphs. Another difficulty is the high susceptibility of magnetic iron oxide NPs to (re)oxidation of ferrous ions $\left(\mathrm{Fe}^{2+}\right)$ to ferric ions $\left(\mathrm{Fe}^{3+}\right)$ under atmospheric conditions, especially when they are in the nano-size range. The main principle of formation of metal and metal oxide nanoparticles by gamma-irradiation of an aqueous solution of a metal salt or within a hydrogel is the reduction of metal cations $\left(\mathrm{M}^{\mathrm{n}+}\right)$ by hydrated electrons $\left(\mathrm{e}_{\mathrm{aq}}^{-}\right)\left(E^{\mathrm{o}}\left(\mathrm{H}_{2} \mathrm{O} / \mathrm{e}_{\mathrm{aq}}^{-}\right)=-2.87 \mathrm{~V}_{\mathrm{SHE}}\right)$ and proton radicals $(\mathrm{H} \cdot)\left(E^{\mathrm{o}}\left(\mathrm{H}^{+} / \mathrm{H}^{\bullet}\right)=-2.30 \mathrm{~V}_{\mathrm{SHE}}\right)$ which are strong reducing agents formed on water radiolysis [29],

$$
\mathrm{H}_{2} \mathrm{O} M \mathrm{e}_{\mathrm{aq}}^{-} \mathrm{H}^{\cdot}, \cdot \mathrm{OH}, \mathrm{H}_{2} \mathrm{O}_{2}, \mathrm{HO}_{2} \cdot \mathrm{H}_{2}, \mathrm{O}_{2} \cdot{ }^{-}, \mathrm{H}_{3} \mathrm{O}^{+} \text {. }
$$

These reducing species can easily reduce metal cations with a more positive standard potential to a lower oxidation state or zero-valence state, such as ferric ions to ferrous $\left(E^{\mathrm{o}}\left(\mathrm{Fe}^{3+} / \mathrm{Fe}^{2+}\right)=+0.77 \mathrm{~V}\right)$ or even $\mathrm{Fe}^{0}\left(\left(E^{\mathrm{O}}\left(\mathrm{Fe}^{3+} / \mathrm{Fe}^{0}\right)=-0.04 \mathrm{~V} ; E^{\mathrm{O}}\left(\mathrm{Fe}^{2+} / \mathrm{Fe}^{0}\right)=-0.44 \mathrm{~V}\right)[18,26]\right.$. Due to the high energy and penetration of $\gamma$-radiation, strong reducing species are formed homogeneously throughout the system, resulting in homogeneous NPs nuclei formation. On the other hand, hydroxyl radicals $\left({ }^{\bullet} \mathrm{OH}\right)$, as well as $\mathrm{HO}_{2}{ }^{\bullet}$ and $\mathrm{O}_{2}{ }^{\bullet-}$ radicals formed on water radiolysis, are strong oxidizing species $\left(\mathrm{V}_{\mathrm{NHE}}, E^{\mathrm{O}}\left({ }^{\bullet} \mathrm{OH} / \mathrm{H}_{2} \mathrm{O}\right)\right.$ $\left.=+2.34 \mathrm{~V}_{\mathrm{NHE}}\right)$. In order to ensure strong reducing conditions, irradiation is carried out in deoxygenated solutions and with the addition of scavengers of hydroxyl radicals, such as 2-propanol. The formed 2-propanol radicals can also reduce metal cations $\left(E^{\mathrm{o}}\left(\left(\mathrm{CH}_{3}\right)_{2} \mathrm{CO} /\left(\mathrm{CH}_{3}\right)_{2} \mathrm{C}^{\bullet} \mathrm{OH}=-1.8 \mathrm{~V}_{\mathrm{NHE}}\right)\right.$. 
In our previous works, we synthesized different magnetic iron oxide NPs using $\gamma$-irradiation in the presence of various polymers and surfactants (polyvinylpyrrolidone (PVP), cetyltrimethylammonium bromide (CTAB), DEAE-dextran, dextran sulfate) [23-25] and within microemulsion droplets [20,21] in order to control the stability of the synthesized magnetic suspensions and the size and morphology of the nanoparticles. The aim of this work was to explore the ability of $\gamma$-irradiation technique for the one-step synthesis of magnetic poly(ethylene oxide)/Fe-oxide (PEO/Fe-oxide) nanocomposite hydrogels. PEO was selected because it is a semicrystalline, hydrophilic and biocompatible polymer with numerous applications in pharmacy and biomedicine. For instance, it is used as wound dressings and hydrogels for active substance release. Upon $\gamma$-irradiation of PEO aqueous solutions, PEO easily crosslinks and forms macroscopic "wall-to-wall" hydrogels [12,30-33]. In this work, we optimized the experimental conditions and synthesized magnetic PEO/iron oxide nanocomposite hydrogels in one step starting from an alkaline aqueous suspension of $\mathrm{PEO}$ and $\mathrm{Fe}^{3+}$ precursor. In addition, the influence of $\gamma$-irradiation dose and concentrations of $\mathrm{Fe}^{3+}$ precursor and PEO on the microstructural, thermal and rheological properties of such one-step synthesized magnetic nanocomposite gels was studied.

\section{Materials and Methods}

\subsection{Chemicals for the Synthesis}

All chemicals were of analytical purity and used as received. Iron(III) chloride hexahydrate $\left(\mathrm{FeCl}_{3} \cdot 6 \mathrm{H}_{2} \mathrm{O}\right)$ (puriss. p.a., Reag. Ph. Eur., $\geq 99 \%$ ) produced by Sigma-Aldrich, St. Louis, MO, USA; sodium hydroxide (anhydrous, free-flowing, pellets, ACS reagent, $\geq 97 \%$ ) by Sigma-Aldrich,

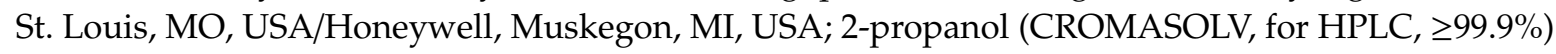
by Sigma-Aldrich, St. Louis, MO, USA/Honeywell, Muskegon, MI, USA; poly(ethylene oxide) (PEO) of viscosity average molecular weight $\left(\mathrm{M}_{\mathrm{V}}\right)$ 400,000 by Sigma-Aldrich, St. Louis, MO, USA and Mili-Q deionized water were used.

\subsection{Synthesis of Samples}

Iron(III) chloride salt was used for the synthesis of iron oxide nanoparticles. PEO/iron(III) precursor suspensions were prepared by firstly dissolving PEO powder to prepare $1.85 \mathrm{wt} \%$ aqueous solutions, followed by the addition of $2 \mathrm{M} \mathrm{FeCl}_{3}$ aqueous solution to the final concentrations of initial Fe $\mathrm{Fens}^{3+}$ ions in solutions being $0.35 \times 10^{-2} \mathrm{M}, 1.75 \times 10^{-2} \mathrm{M}$, and $7 \times 10^{-2} \mathrm{M}$. These $\mathrm{Fe}^{3+}$ concentrations in solutions correspond to mass percentages of $\mathrm{Fe}^{3+}$ of 1,5,20 $\mathrm{wt} \%$ relative to total $\mathrm{PEO}$ and $\mathrm{Fe}^{3+}$ mass, respectively. In addition, one batch of precursor solutions wasprepared from $4 \mathrm{wt} \%$ PEO aqueous solutions with the same concentrations of $\mathrm{Fe}^{3+}$ salt. The solutions were irradiated with or without 2-propanol. The final concentration of 2-propanol in solutions was $0.2 \mathrm{M}$. In addition, few solutions were prepared containing four times more 2-propanol $(0.8 \mathrm{M})$. The $\mathrm{pH}$ of suspensions was adjusted to $\mathrm{pH}=11.5-12$ with $2 \mathrm{M}$ $\mathrm{NaOH}$ aqueous solution. The prepared precursor suspensions were bubbled with nitrogen through rubber septa for $30 \mathrm{~min}$ in order to remove dissolved oxygen before $\gamma$-irradiation. $\gamma$-irradiation of deoxygenated suspensions in septum-closed glass vials was performed at room temperature in a ${ }^{60}$ Co $\gamma$-irradiation facility located in the Radiation Chemistry and Dosimetry Laboratory at the Ruđer Bošković Institute. The suspensions were irradiated to doses of 50, 130 and 300 kGy and at a dose rate of $\sim 27 \mathrm{kGy} \mathrm{h}^{-1}$. Irradiation of PEO/Fe(III) precursor suspensions resulted in the formation of gels or suspensions. The schematic presentation of the synthesis procedure of magnetic PEO/iron oxide nanocomposite hydrogels is given in Figure 1. 


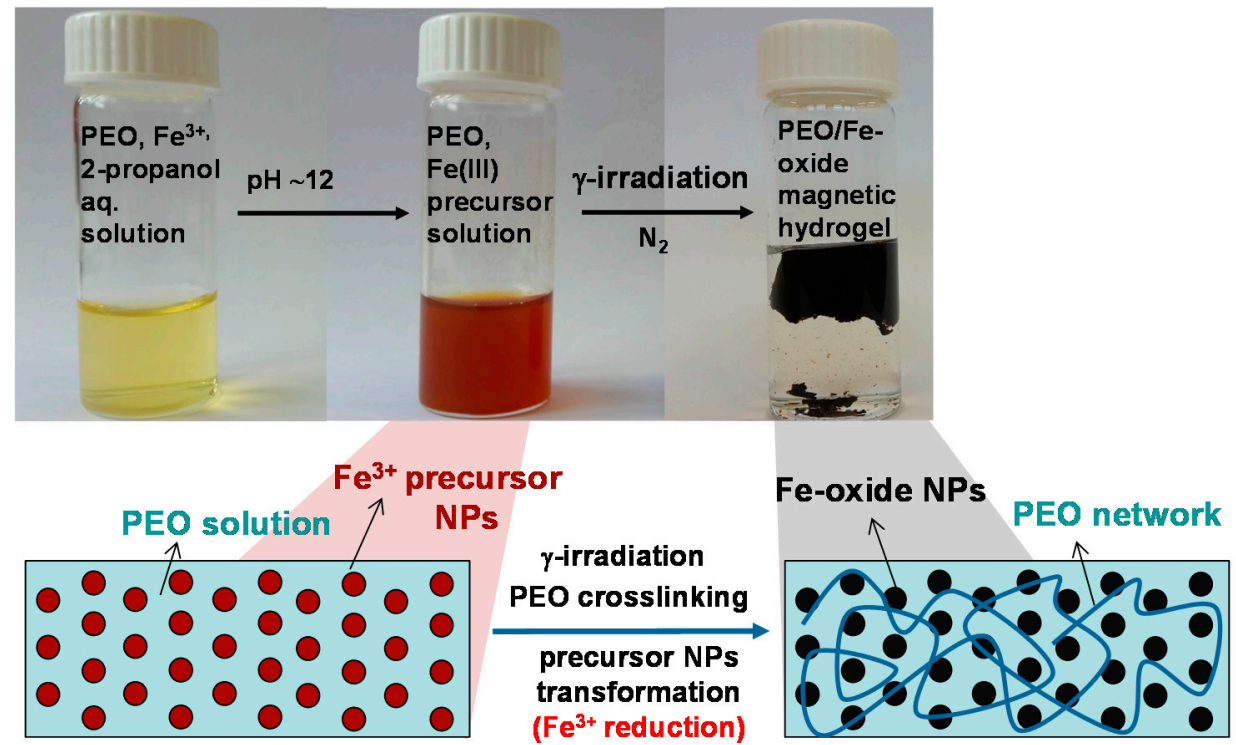

Figure 1. Schematic presentation of the synthesis procedure of magnetic poly(ethylene oxide) (PEO)/iron oxide nanocomposite hydrogels.

\subsection{Characterization of Samples}

Synthesized samples were characterized as as-synthesized gels (rheological measurements), as dried gels (DSC, XRD, Mössbauer, SEM) or as suspensions/isolated precipitates (XRD, Mössbauer). Precipitates were isolated from suspensions by centrifugation, followed by washing with ethanol. Scanspeed 2236R high-speed centrifuge was used. The obtained gels and isolated precipitates were dried in vacuum at room temperature, and then characterized.

The morphology of samples was investigated using a probe Cs-corrected cold field-emission Scanning Transmission Electron Microscope (STEM, model ARM 200 CF), and the thermal field emission scanning electron microscope (FE SEM, model JSM-7000F) manufactured by JEOL Ltd., Tokyo, Japan, FE SEM was linked to the EDS/INCA 350 (energy-dispersive X-ray analyzer) manufactured by Oxford Instruments Ltd., Abingdon, UK.

X-ray powder diffraction (XRD) patterns were recorded at room temperature using an APD 2000 $\mathrm{X}$-ray powder diffractometer $(\mathrm{CuK} \alpha$ radiation, graphite monochromator, $\mathrm{NaI}-\mathrm{Tl}$ detector) manufactured by ItalStructures, Riva Del Garda, Italy. The XRD patterns were recorded over the $15-80^{\circ} 2 \theta$ range with a $2 \theta$ step of $0.05-0.025^{\circ}$ and a counting time per step of $15-80 \mathrm{~s}$.

${ }^{57} \mathrm{Fe}$ Mössbauer spectra were recorded at $20{ }^{\circ} \mathrm{C}$ in the transmission mode using a standard instrumental configuration by WissEl GmbH, Mömbris-Hohl, Germany. The ${ }^{57} \mathrm{Co}$ in the rhodium matrix was used as a Mössbauer source. The spectrometer was calibrated at $20^{\circ} \mathrm{C}$ using the standard $\alpha$-Fe foil spectrum. The velocity scale and all the data refer to the metallic $\alpha$-Fe absorber at $20^{\circ} \mathrm{C}$. The experimentally observed Mössbauer spectra were fitted using the MossWinn program. Additionally, ${ }^{57} \mathrm{Fe}$ Mössbauer spectra were recorded at $77 \mathrm{~K}$ using a conventional constant acceleration transmission spectrometer with a ${ }^{57} \mathrm{Co}(\mathrm{Rh})$ source and a bath cryostat. The spectra obtained at $77 \mathrm{~K}$ were fitted using the MOSFIT program (Teillet, J.; Varret, F. unpublished MOSFIT program, Université du Maine) and an $\alpha$-Fe absorber was used as a calibration sample.

Differential scanning calorimetry (DSC) thermograms were recorded using PerkinElmer, Waltham, MA, USA Diamond DSC calorimeter, calibrated with In and Zn standards and operating in a dynamic mode. Samples of dried gel $(5-10 \mathrm{mg})$ were sealed into Al pans. Two heating and cooling cycles at temperatures ranging from $-40{ }^{\circ} \mathrm{C}$ to $100^{\circ} \mathrm{C}$ in an extra pure nitrogen environment were performed for each sample at a rate of $10^{\circ} \mathrm{C} \mathrm{min}{ }^{-1}$. The first heating cycle was performed in a range $22^{\circ} \mathrm{C}$ to $100^{\circ} \mathrm{C}$. For each synthesized gel three specimens were recorded. The temperatures and enthalpies of 
melting and crystallization were determined from the second heating and first cooling cycles, and their averages are presented.

The mechanical properties of gels are described using oscillatory rheology. The storage $\left(G^{\prime}\right)$ and loss $\left(G^{\prime \prime}\right)$ moduli of the nanocomposite gels were determined with a mechanical spectrometer (Anton Paar MCR 302, Stuttgart, Germany), using a steel plate-plate geometry (PP25, Anton Paar, Graz, Austria) equipped with a true-gap system and the data were collected using RheoCompass software. The sample temperature was controlled through a Peltier temperature control located on the base of the geometry and with a Peltier-controlled hood (H-PTD 200). A piece of a gel sample (1 mm thick slice) was placed on the base plate of the rheometer, and the plate was set using the true-gap function of the software. Thus, after $5 \mathrm{~min}$ at $25^{\circ} \mathrm{C}$, the $G^{\prime}$ and $G^{\prime \prime}$ moduli were measured always within the linear viscoelastic region (LVR). After $5 \mathrm{~min}$ at $25^{\circ} \mathrm{C}$, the yield stress of the gels was determined by applying a strain $(\gamma)$ sweep between $0.01 \%$ and $100 \%$. Rheological properties of the gel material are independent of strain up to yield strain, and beyond yield strain the rheological behavior is nonlinear. Three interval thixotropy test is a standard test which allows tracking of material response resulting from stepwise changes in shear strain making it the most appropriate method for structure recovery tests. In the thixotropic experiments, rheological measurements were conducted on gels at $25^{\circ} \mathrm{C}$ under initial conditions at which they were in their linear viscoelastic regimes (a strain of $0.1 \%$ and angular frequency of $5 \mathrm{rad} / \mathrm{s}$ ) for $680 \mathrm{~s}$ to establish baseline values for $G^{\prime}$ and $G^{\prime \prime}$. In studies with gels viscoelastic recovery was observed after the cessation of destructive strain. Frequency sweeps $(0.05-100 \mathrm{rad} / \mathrm{s})$ were subsequently performed at $25{ }^{\circ} \mathrm{C}$ at a strain value within LVR to investigate the time-dependent deformation behavior of gels.

\subsection{Quantitative Determination of $\mathrm{Fe}^{2+}$ Using 1,10-Phenanthroline UV-Vis Spectrophotometric Method}

\subsubsection{Chemicals for Spectrophotometric Determination}

All chemicals were of analytical purity and used as received. Sodium acetate (Merck, Kenilworth, NJ, USA anhydrous for analysis, EMSURE, ACS, Reag. Ph. Eur.), acetic acid (Honeywell, Muskegon, MI, USA puriss.p.a., ACS Reagent, Reag. Ph. Eur., $\geq 99.8 \%$ ), L-ascorbic acid (Sigma-Aldrich, St. Louis, MO, USA BioXtra, crystalline, $\geq 99.0 \%$ ), 1,10-phenanthroline monohydrate (Sigma-Aldrich, St. Louis, MO, USA for the spectrophotometric determination, $\geq 99.0 \%$ ), and hydrochloric acid (Fluka (Honeywell), Muskegon, MI, USA for trace analysis, fuming, $\geq 37 \%$ ) were used.

\subsubsection{Spectrophotometric Determination of $\mathrm{Fe}^{2+}$}

The amount of $\mathrm{Fe}^{2+}$ generated upon $\gamma$-irradiation was determined using the 1,10-phenanthroline method [34,35].

Immediately after irradiation the samples were acidified $(\mathrm{pH} \leq 1)$ by the addition of concentrated hydrochloric acid ( $2.5 \mathrm{vol} \%)$ using a syringe through rubber septa. At such low $\mathrm{pH}$, formed iron oxide nanoparticles are dissolved and all $\mathrm{Fe}^{2+}$ formed upon $\gamma$-irradiation is preserved from oxidation when the vial is opened. The detailed procedure for the determination of $\mathrm{Fe}^{2+}$ and total iron in such acidified solutions is given in our recently published paper [35].

\section{Results and Discussion}

\subsection{Microstructural Characterization of Gels (and Suspensions)}

Upon $\gamma$-irradiation, the reddish $\mathrm{PEO} / \mathrm{Fe}(\mathrm{III})$ suspensions turned to reddish or white-green or black gels or black suspensions depending on the dose, 2-propanol concentration and the amount of $\mathrm{Fe}^{3+}$. The photographs of formed nanocomposite gels are shown in Figure 2. 


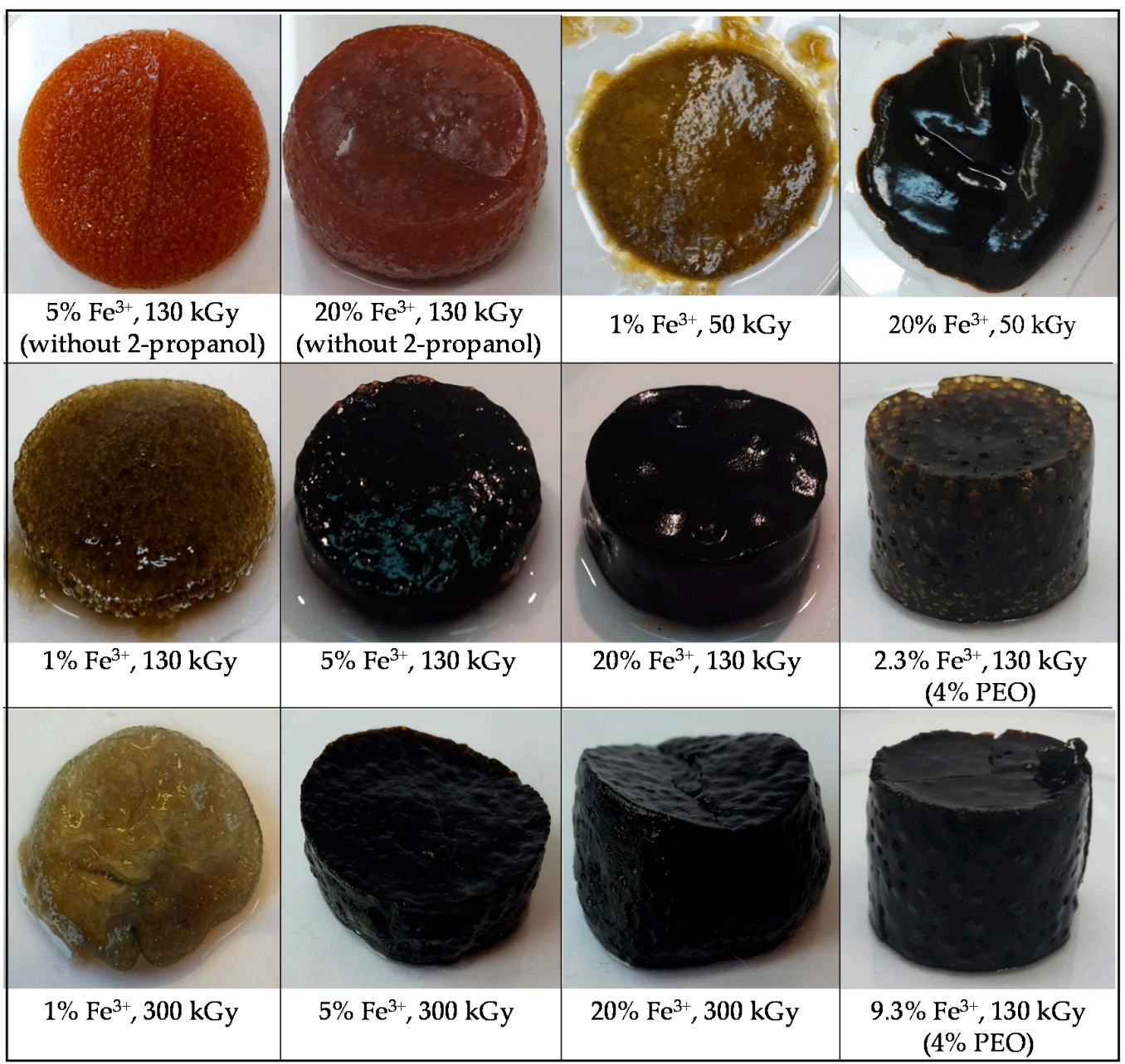

Figure 2. The photographs of $\mathrm{PEO} / \mathrm{Fe}$-oxide nanocomposite gels obtained from suspension with various $\mathrm{Fe}^{3+}$ content at various doses. Unless otherwise indicated, the precursor suspensions were prepared from $1.85 \mathrm{wt} \%$ PEO solutions and with the addition of 2-propanol $(0.2 \mathrm{M})$.

$\gamma$-irradiation of pure PEO solutions $(1.85 \mathrm{wt} \%)$ and $\mathrm{PEO} / \mathrm{Fe}(\mathrm{III})$ precursor suspensions at $\mathrm{pH} \sim$ 12 without the addition of 2-propanol resulted in the formation of a permanent shape "wall-to-wall" macroscopic gels. The resulting nanocomposite gels were reddish-brown and non-magnetic. The reddish color and non-magnetic behavior indicated that even at the highest dose of $300 \mathrm{kGy}$ no significant reduction of Fe(III) occurred (Figure 2). The reducing conditions were improved by the addition of 2-propanol ( $0.2 \mathrm{M})$. Irradiation of the pure $1.85 \mathrm{wt} \%$ PEO solution in the presence of 2-propanol did not lead to gel formation. On the other hand, the irradiation of $\mathrm{PEO} / \mathrm{Fe}(\mathrm{III})$ precursor suspensions at $\mathrm{pH} 12$ in the presence of 2-propanol led to the formation of nanocomposite gels (Figure 2). The white-green gels were obtained from $1 \mathrm{wt} \% \mathrm{Fe}^{3+}$ suspensions, while the black magnetic hydrogels were obtained upon irradiation of 5 and $20 \mathrm{wt} \% \mathrm{Fe}^{3+}$ suspensions at higher doses (130 and $300 \mathrm{kGy}$ ). The gel obtained from $20 \% \mathrm{Fe}^{3+}$ suspensions at $300 \mathrm{kGy}$ was strongly attracted by a permanent magnet as shown in Figure 3.

Figure 4 shows FE SEM images of composite gels obtained upon irradiation of suspensions with 2-propanol. The nanoparticles embedded into the polymer matrix are visible. Particles were mainly spherical in shape. The gel at $300 \mathrm{kGy}$ and $20 \mathrm{wt} \% \mathrm{Fe}^{3+}$ (Figure $4 \mathrm{f}$ ) consisted of numerous spherical particles and/or particle aggregates of $40 \mathrm{~nm}$ in size homogeneously distributed throughout the polymer matrix. The SEM image of gel at $300 \mathrm{kGy}$ and $5 \mathrm{wt} \% \mathrm{Fe}^{3+}$ (Figure 4e) reveals the presence of larger irregular plate-like particles $70 \mathrm{~nm}$ in size, in addition to much smaller spherical ones. 


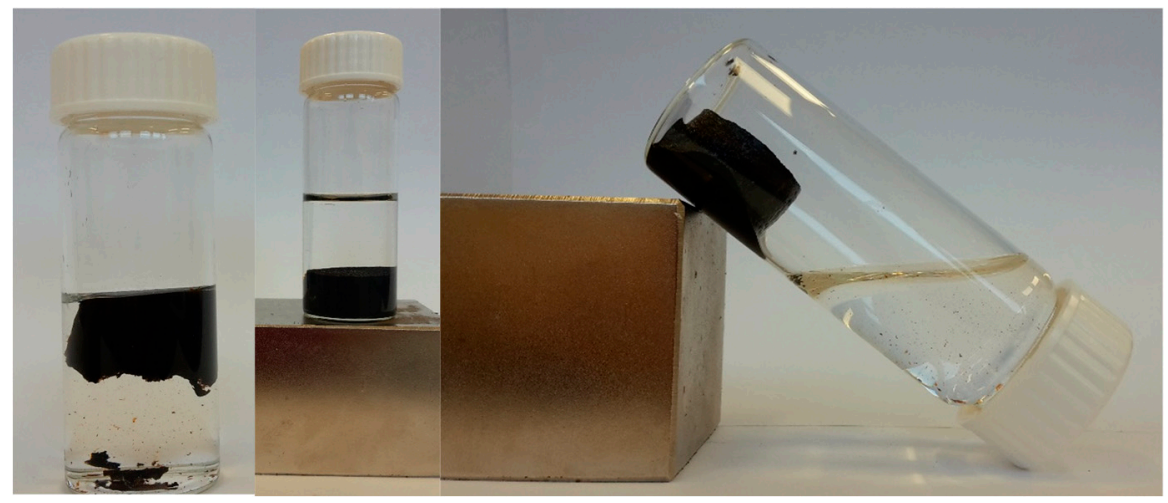

Figure 3. The photographs of magnetic PEO/iron oxide gel attracted by a permanent magnet.
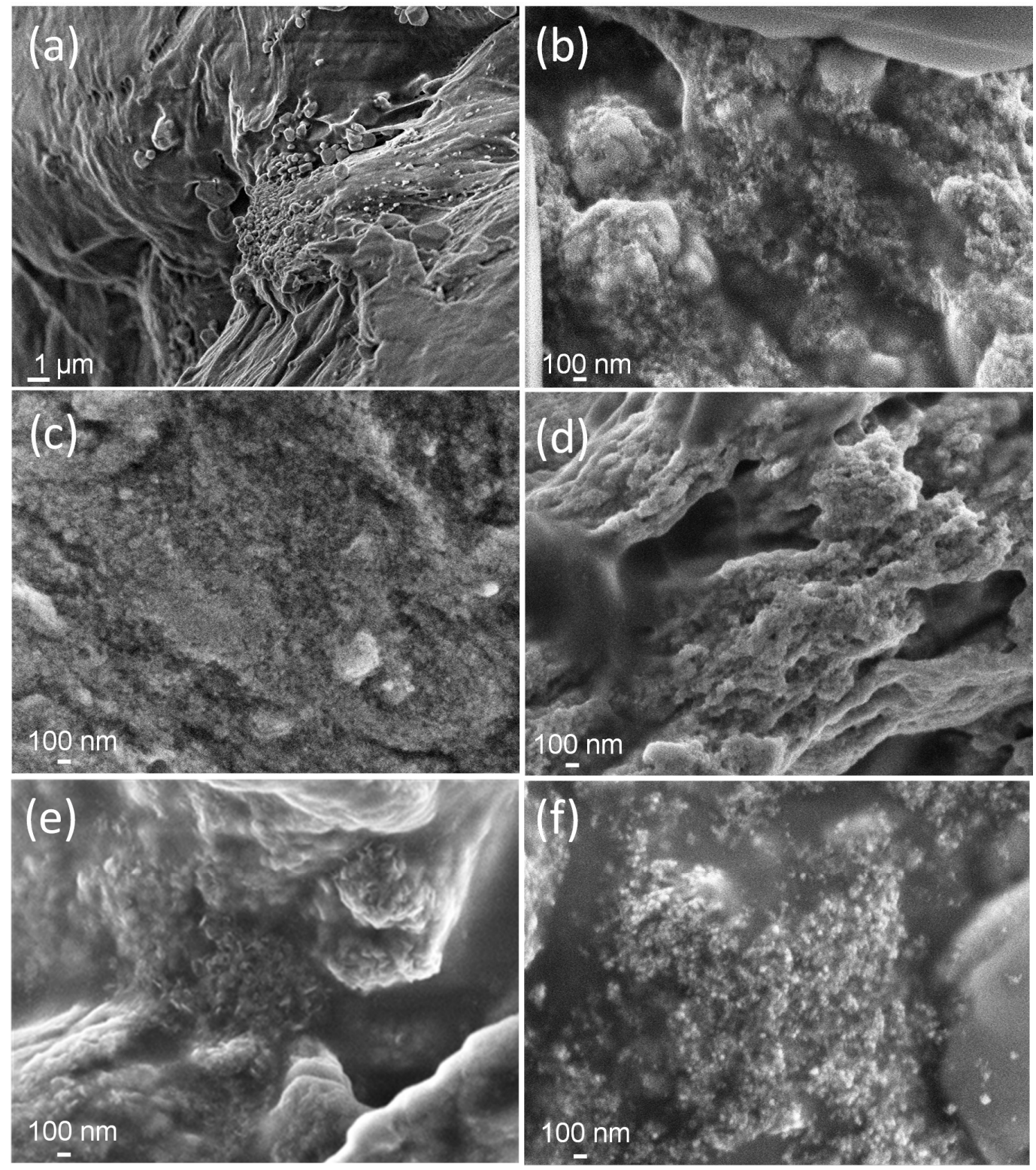

Figure 4. SEM micrographs of $\mathrm{PEO} / \mathrm{Fe}$-oxide gels obtained from suspensions with various $\mathrm{Fe}^{3+}$ content at various doses: (a) $5 \mathrm{wt} \% \mathrm{Fe}^{3+}$ at $50 \mathrm{kGy}$; (b) $20 \mathrm{wt} \% \mathrm{Fe}^{3+}$ at $50 \mathrm{kGy}$; (c) $5 \mathrm{wt}^{\mathrm{m}} \mathrm{Fe}^{3+}$ at $130 \mathrm{kGy}$; (d) $20 \mathrm{wt} \% \mathrm{Fe}^{3+}$ at $130 \mathrm{kGy}$; (e) $5 \mathrm{wt} \% \mathrm{Fe}^{3+}$ at $300 \mathrm{kGy}$; (f) $20 \mathrm{wt} \% \mathrm{Fe}^{3+}$ at $300 \mathrm{kGy}$. All precursor suspensions were prepared from $1.85 \mathrm{wt} \%$ PEO solutions and with $0.2 \mathrm{M}$ 2-propanol. 
Figure 5 shows the Mössbauer spectra recorded at $77 \mathrm{~K}$ of nanocomposite gels obtained from suspensions with 2-propanol at $130 \mathrm{kGy}$ and $300 \mathrm{kGy}$. Generally, the Mössbauer spectrometry is very sensitive to the presence of Fe(II) in inorganic [25,36] and biological samples [37]. The sample 5\% $\mathrm{Fe}^{3+}$ at $130 \mathrm{kGy}$ (Figure 5a) consisted of a symmetric doublet which was fitted with quadrupole splitting distribution. Even at this low-temperature the sample was not magnetically ordered, which reveals the ultrasmall particle size. This quadrupole splitting distribution can be ascribed to a poorly crystalline, disordered structure (average quadrupole splitting $<\Delta>$ for $5 \%$ Fe sample is $0.79 \mathrm{~mm} \mathrm{~s}^{-1}$ (Figure 5a) and for $20 \%$ Fe sample is $0.82 \mathrm{~mm} \mathrm{~s}^{-1}$ (Figure $5 \mathrm{~b}$ )). Average isomer shift values of $<\delta>=0.45 \mathrm{~mm} \mathrm{~s}^{-1}$ for both samples are consistent with those of $\mathrm{Fe}^{3+}$ [38]. The spectrum of gel obtained at $300 \mathrm{kGy}$ and $5 \% \mathrm{Fe}^{3+}$ consisted of a quadrupole splitting distribution component and the doublet whose parameters correspond to $\mathrm{Fe}^{2+}\left(\delta=1.24 \mathrm{~mm} \mathrm{~s}^{-1}, \Delta=2.68 \mathrm{~mm} \mathrm{~s}^{-1}\right)$ (Figure $\left.5 \mathrm{c}\right)$. The gel obtained at $300 \mathrm{kGy}$ and $20 \% \mathrm{Fe}^{3+}$ exhibited a collapsing sextet (Figure 5d). Such spectrum is generally found with systems that exhibit superparamagnetic relaxation phenomena. This spectrum was best fitted with a distribution of the hyperfine magnetic field (average $<B_{\mathrm{hf}}>$ was $23.6 \mathrm{~T}$ ). The fit resulted in a bimodal distribution, which indicates that the sample consists of two types of particles; a population with the bigger particle size whose magnetic relaxation time is longer than the measurement time of ${ }^{57} \mathrm{Fe}$ Mössbauer spectrometry $\left(5 \times 10^{-8} \mathrm{~s}\right)$, and a population of smaller particles whose relaxation time is somewhat shorter than the measurement time of Mössbauer spectrometry. The symmetric nature of the spectrum suggests that there is no $\mathrm{Fe}^{2+}$ in the sample. Furthermore, the fact that the isomer shift value is $0.45 \mathrm{~mm} \mathrm{~s}^{-1}$ and quadrupole shift is $0.00 \mathrm{~mm} \mathrm{~s}^{-1}$, which are the usual values for poorly crystalline maghemite sextet at $77 \mathrm{~K}$ [39], indicates that the sample is composed of maghemite. The spectra measured at $300 \mathrm{~K}$ are shown in Figure S1 in the Supplementary Materials (all spectra at room temperature are consistent with superparamagnetic and/or paramagnetic doublets).
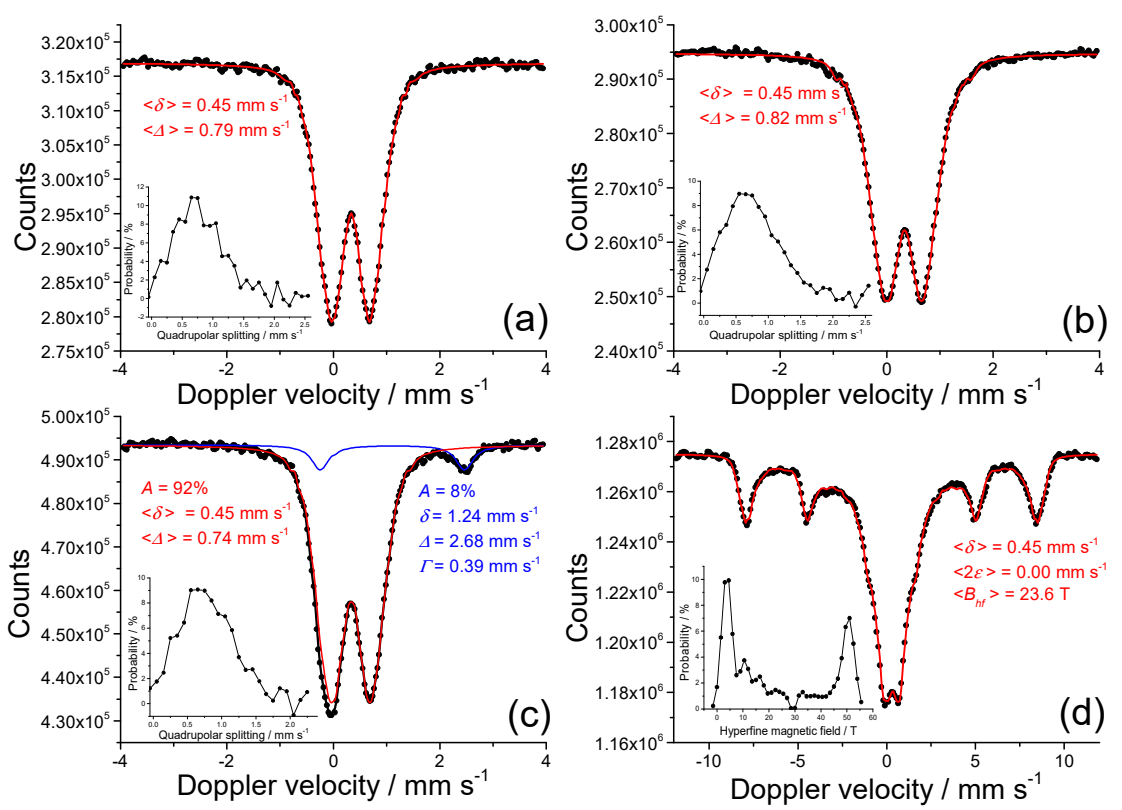

Figure 5. The $77 \mathrm{~K}$ Mössbauer spectra of PEO/Fe-oxide gels obtained from suspensions with: $5 \mathrm{wt} \%$ $\mathrm{Fe}^{3+}$ at $130 \mathrm{kGy}(\mathbf{a}) ; 20 \mathrm{wt} \% \mathrm{Fe}^{3+}$ at $130 \mathrm{kGy}(\mathbf{b}) ; 5 \mathrm{wt} \% \mathrm{Fe}^{3+}$ at $300 \mathrm{kGy}(\mathbf{c}) ; 20 \mathrm{wt} \% \mathrm{Fe}^{3+}$ at $300 \mathrm{kGy}(\mathbf{d})$. All precursor suspensions were prepared from $1.85 \mathrm{wt} \%$ PEO solutions and with $0.2 \mathrm{M}$ 2-propanol. Mössbauer parameters are given: $\delta=$ isomer shift relative to $\alpha$-Fe at $20^{\circ} \mathrm{C} ; \Delta=$ quadrupole splitting; $\Gamma=$ line width; $B_{\mathrm{hf}}=$ hyperfine field, $\mathrm{A}=$ relative area. $\Delta$ values are given as an average value of quadrupole splitting distributions $(\mathbf{a}-\mathbf{c})$. $B_{\mathrm{hf}}$ value is given as an average value of hyperfine field distribution (d). Line width values were fixed during the fitting of quadrupole splitting distribution $(\mathbf{a}-\mathbf{c})$ or hyperfine field distribution (d). Error: $\delta= \pm 0.01 \mathrm{~mm} \mathrm{~s}^{-1} ; \Delta= \pm 0.01 \mathrm{~mm} \mathrm{~s}^{-1} ; B_{\mathrm{hf}}= \pm 0.3 \mathrm{~T}$. 
Figure 6 presents the XRD patterns of unirradiated precursor (Figure 6a) and PEO/Fe-oxide gels obtained upon irradiation of suspensions with 2-propanol (0.2 M) and $5 \mathrm{wt} \% \mathrm{Fe}^{3+}$ at $50 \mathrm{kGy}$ (Figure $6 \mathrm{~b}$ ), $130 \mathrm{kGy}$ (Figure 6c) and $300 \mathrm{kGy}$ (Figure 6d), as well as $20 \mathrm{wt} \% \mathrm{Fe}^{3+}$ at $130 \mathrm{kGy}$ (Figure 6e) and 300 kGy (Figure 6f). The XRD patterns (Figure 6a-e) show two maxima which can be attributed to iron oxide phases. The XRD patterns of the precursor and the gel obtained at $50 \mathrm{kGy}$ (Figure 6a,b) were ascribed to ferrihydrite and $\mathrm{NaCl}$ as an impurity. The XRD patterns of gels obtained at 130 and $300 \mathrm{kGy}$ (Figure 6a-e) were attributed to magnetite NPs. On the other hand, the gel obtained from $20 \mathrm{wt} \%$ $\mathrm{Fe}^{3+}$ suspension at $300 \mathrm{kGy}$ (Figure 6f) had sharper and more distinct maxima, indicating improved crystallinity of the formed magnetite NPs, which is in line with the results of Mössbauer spectrometry. The distinct maxima at $\sim 19$ and $\sim 23^{\circ}$ on the XRD patterns of composite gels obtained at 50 and $130 \mathrm{kGy}$ are the result of partial crystallization of PEO gels upon drying. These maxima completely disappeared on the XRD pattern of nanocomposite gel obtained at $300 \mathrm{kGy}$ and only wide amorphous halo is visible, due to the very dense crosslinking density of gel obtained at $300 \mathrm{kGy}$. The results of line broadening analyses are given in Table 1 . The volume-averaged domain sizes $\left(D_{\mathrm{v}}\right)$ of the dominant crystalline phase in the synthesized samples were estimated using the Scherrer equation:

$$
D_{h k l}=0.9 \lambda /\left(\beta_{h k l} \times \cos \theta\right)
$$

where $D_{h k l}$ is the volume average domain size in the direction normal to the reflecting planes $(h k l), \lambda$ is the X-ray wavelength $(\mathrm{CuK \alpha}), \theta$ is the Bragg angle, and $\beta_{h k l}$ is the pure full width of the diffraction line $(h k l)$ at half the maximum intensity. The volume-average domain size $\left(D_{\mathrm{v}}\right)$ of the 110 lines $\left(D_{110}\right)$ of ferrihydrite in the unirradiated precursor was estimated to 1.7 , whereas upon $\gamma$-irradiation to $50 \mathrm{kGy}$ the average domain size increased to $4.5 \mathrm{~nm}$ (Table 1). At $130 \mathrm{kGy}$ and $300 \mathrm{kGy}\left(5 \mathrm{wt}^{\mathrm{o}} \mathrm{Fe}^{3+}\right.$ ) ferrihydrite transformed to magnetite of about $2.3 \mathrm{~nm}$ in size $\left(D_{311} \cong 2.3 \mathrm{~nm}\right)$. The sample irradiated with the dose of $130 \mathrm{kGy}$ with $20 \mathrm{wt} \% \mathrm{Fe}^{3+}$ had a somewhat larger crystallite size $\left(D_{311} \cong 3.3 \mathrm{~nm}\right)$ than the sample prepared from suspension with lower $\mathrm{Fe}^{3+}$ concentration, which is expected. However, at $300 \mathrm{kGy}$ and $20 \mathrm{wt} \% \mathrm{Fe}^{3+}$ the crystallite size of magnetite nanoparticles increased significantly when compared to the $130 \mathrm{kGy}$ sample. This significant increase in the crystallinity of nanoparticles was not observed for gels prepared from suspensions lower initial $\mathrm{Fe}^{3+}$ concentration where the magnetite crystallite size did not change noticeably.

TEM analysis of gel obtained at $130 \mathrm{kGy}$ from suspension with $20 \mathrm{wt} \% \mathrm{Fe}^{3+}$ is shown in Figure 7. Figure 7a shows the STEM bright-field micrograph of the gel with slightly high-frequency FFT filtered BF-STEM image of very thin area (where individual Fe atom columns can bee seen in some nanoparticles). The very small $(\sim 3 \mathrm{~nm})$ particles can be seen confirming the results obtained by XRD line-broadening analysis. The much larger particle size observed using SEM in the scattering mode (Figure 4) compared to the TEM determination in the transmission mode (Figure 7a) is because the SEM sees the iron oxide nanoparticles "disguised" by polymer whereas the TEM can see the "pure" individual iron oxide nanoparticles. EDXS (energy-dispersive X-ray spectroscopy) elemental mapping (Figure $7 \mathrm{~b}$ ) shows that three major elements are iron, oxygen, and carbon, and that they are homogeneously distributed throughout the sample indicating good dispersion of nanoparticles within the gel matrix. SAED (selected area electron diffraction) patterns (Figure 7c,d) match magnetite and $\mathrm{NaCl}$ impurity thus confirming the results of XRD, i.e., the formation of magnetite nanoparticles inside the PEO gel. The Mössbauer results suggested that magnetite nanoparticles were completely oxidized to maghemite. This discrepancy arises because the SAED measures the sample in high vacuum under reducing conditions. On the contrary, Mössbauer spectrometry is very sensitive to Fe(II) at the ambient conditions, and as a rule the Mössbauer spectrometry for small nanoparticles below 5 nm shows no $\mathrm{Fe}(\mathrm{II})$. This is because very small magnetite nanoparticles can easily be oxidized in air.

The amount of $\mathrm{Fe}^{2+}$ generated upon $\gamma$-irradiation was quantitatively determined using 1,10-phenanthroline UV-Vis spectrophotometric method. Figure 8 shows the $\mathrm{Fe}^{2+}$ fraction $\left(\left[\mathrm{Fe}^{2+} /\left(\mathrm{Fe}^{2+}+\mathrm{Fe}^{3+}\right)\right]\right)$ in the $\gamma$-irradiated samples prior to their isolation and coming in contact with air. This was obtained by the addition of concentrated $\mathrm{HCl}$ immediately after irradiation through 
rubber septa (described in experimental). The $\mathrm{Fe}^{2+}$ molar fraction depended on dose, $\mathrm{pH}$ and initial concentration of $\mathrm{Fe}^{3+}$ in precursor suspensions. The $\mathrm{Fe}^{2+}$ fraction increased with the increase of dose and $\mathrm{pH}$ and with the lower initial $\mathrm{Fe}^{3+}$ concentration. At $130 \mathrm{kGy}$ and initial $5 \mathrm{wt} \% \mathrm{Fe}^{3+}$ the reduction yield was $34 \%$ in comparison to $22 \%$ in gels obtained from $20 \mathrm{wt} \% \mathrm{Fe}^{3+}$ suspension. The reduction yield of $31 \%$ obtained for the sample at $300 \mathrm{kGy}$ from $20 \mathrm{wt} \% \mathrm{Fe}^{3+}$ suspension resulted in a highly magnetic gel. The highest reduction yield of $\mathrm{Fe}^{2+}(54.7 \%)$ was achieved at the dose of $300 \mathrm{kGy}, \mathrm{pH}=12$ for $5 \% \mathrm{Fe}^{3+}$ precursor suspension. It should be noted that at similar experimental conditions the $\gamma$-irradiation in the presence of dextran sulfate or DEAE-dextran polymer generated almost $100 \%$ of $\mathrm{Fe}^{2+}$ at $130 \mathrm{kGy}[25,35]$. More reducing conditions were obtained at higher $\mathrm{pH}$. This can be explained by the higher yield of hydrated electrons in a highly alkaline medium [19,40-43]. In an alkaline medium, the hydrogen atoms are converted to hydrated electrons. Because of the fact that the higher reducing conditions were obtained at higher $\mathrm{pH}$, all investigated gels were synthesized at $\mathrm{pH} \sim 12$.
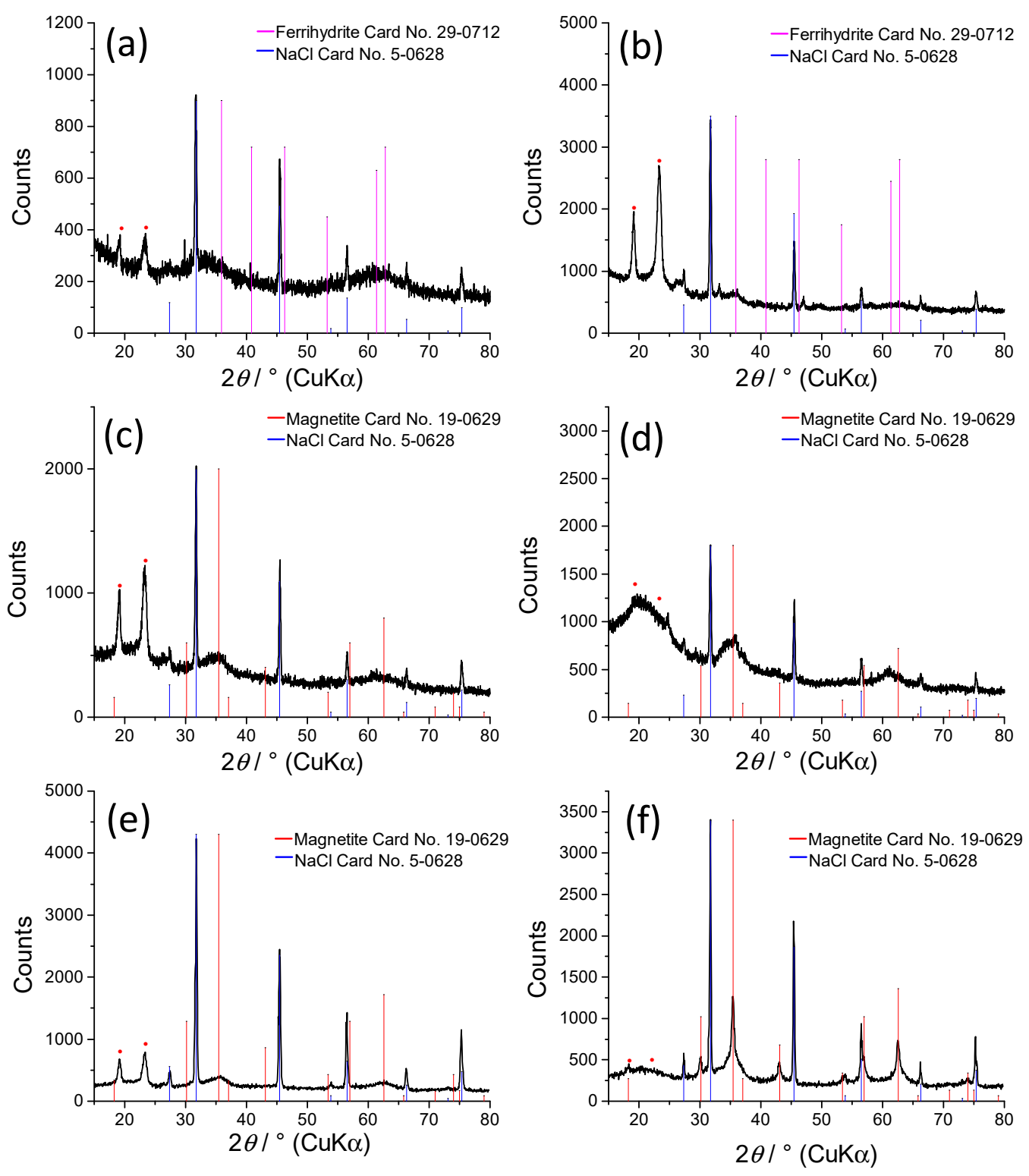

Figure 6. XRD patterns of unirradiated precursor (a) and PEO/Fe-oxide gels obtained from suspensions with: $5 \mathrm{wt} \% \mathrm{Fe}^{3+}$ at $50 \mathrm{kGy}\left(\right.$ b), $5 \mathrm{wt} \% \mathrm{Fe}^{3+}$ at $130 \mathrm{kGy}(\mathbf{c}), 5 \mathrm{wt} \% \mathrm{Fe}^{3+}$ at $300 \mathrm{kGy}$ (d) $20 \mathrm{wt} \% \mathrm{Fe}^{3+}$ at $130 \mathrm{kGy}(\mathbf{e})$ and $20 \mathrm{wt} \% \mathrm{Fe}^{3+}$ at $300 \mathrm{kGy}(\mathbf{f})$, at $\mathrm{pH} \sim 12$. The two maxima at $\sim 19$ and $\sim 23$ degrees marked with red dots correspond to crystalline PEO. 
Table 1. The volume-averaged domain size $\left(D_{\mathrm{V}}\right)$ of the dominant crystalline phase of selected samples.

\begin{tabular}{|c|c|c|c|c|c|}
\hline Sample & Phase & $h k l$ & $2 \theta /^{\circ}$ & FWHM/ $/^{\circ}$ & $D_{h k l} / \mathrm{nm}$ \\
\hline $\begin{array}{l}\text { unirradiated precursor (5 wt } \% \\
\mathrm{Fe}^{3+}, 0.2 \mathrm{M} \text { 2-propanol) }\end{array}$ & $\begin{array}{l}\text { ferrihydrite } \\
\text { PEO + halite } \\
\text { (impurity) }\end{array}$ & 110 & $\sim 35$ & 5.1 & 1.7 \\
\hline $\begin{array}{c}\text { gel - } 50 \mathrm{kGy}\left(5 \mathrm{wt} \% \mathrm{Fe}^{3+}, 0.2 \mathrm{M}\right. \\
\text { 2-propanol) }\end{array}$ & $\begin{array}{l}\text { ferrihydrite } \\
\text { PEO + halite } \\
\text { (impurity) }\end{array}$ & 110 & 35.8 & 1.9 & 4.5 \\
\hline $\begin{array}{c}\text { gel - } 130 \mathrm{kGy}\left(5 \mathrm{wt} \% \mathrm{Fe}^{3+}, 0.2 \mathrm{M}\right. \\
\text { 2-propanol) }\end{array}$ & $\begin{array}{l}\text { magnetite } \\
\text { PEO + halite } \\
\text { (impurity) }\end{array}$ & 311 & 35.5 & 3.6 & 2.3 \\
\hline $\begin{array}{c}\text { gel - } 300 \mathrm{kGy}\left(5 \mathrm{wt} \% \mathrm{Fe}^{3+}, 0.2 \mathrm{M}\right. \\
\text { 2-propanol) }\end{array}$ & $\begin{array}{c}\text { magnetite } \\
\text { halite }+ \text { unidentified } \\
\text { impurity }\end{array}$ & - & 35.3 & 3.5 & 2.4 \\
\hline $\begin{array}{c}\text { gel - } 130 \mathrm{kGy}\left(20 \mathrm{wt} \% \mathrm{Fe}^{3+}, 0.2 \mathrm{M}\right. \\
\text { 2-propanol) }\end{array}$ & $\begin{array}{l}\text { magnetite } \\
\text { PEO + halite } \\
\text { (impurity) }\end{array}$ & 311 & 35.5 & 2.6 & 3.3 \\
\hline $\begin{array}{c}\text { gel - } 300 \mathrm{kGy}\left(20 \mathrm{wt} \% \mathrm{Fe}^{3+}, 0.2 \mathrm{M}\right. \\
\text { 2-propanol) }\end{array}$ & $\begin{array}{l}\text { magnetite } \\
\text { PEO + halite } \\
\text { (impurity) }\end{array}$ & 311 & 35.4 & 0.6 & 13.9 \\
\hline $\begin{array}{c}\text { powder - } 50 \mathrm{kGy}\left(20 \mathrm{wt} \% \mathrm{Fe}^{3+}\right. \\
0.8 \mathrm{M} \text { 2-propanol })\end{array}$ & magnetite & 311 & 35.5 & 3.6 & 2.3 \\
\hline $\begin{array}{c}\text { powder - } 130 \mathrm{kGy}\left(20 \mathrm{wt} \% \mathrm{Fe}^{3+},\right. \\
0.8 \mathrm{M} \text { 2-propanol) }\end{array}$ & magnetite & 311 & 35.5 & 2.6 & 3.3 \\
\hline
\end{tabular}

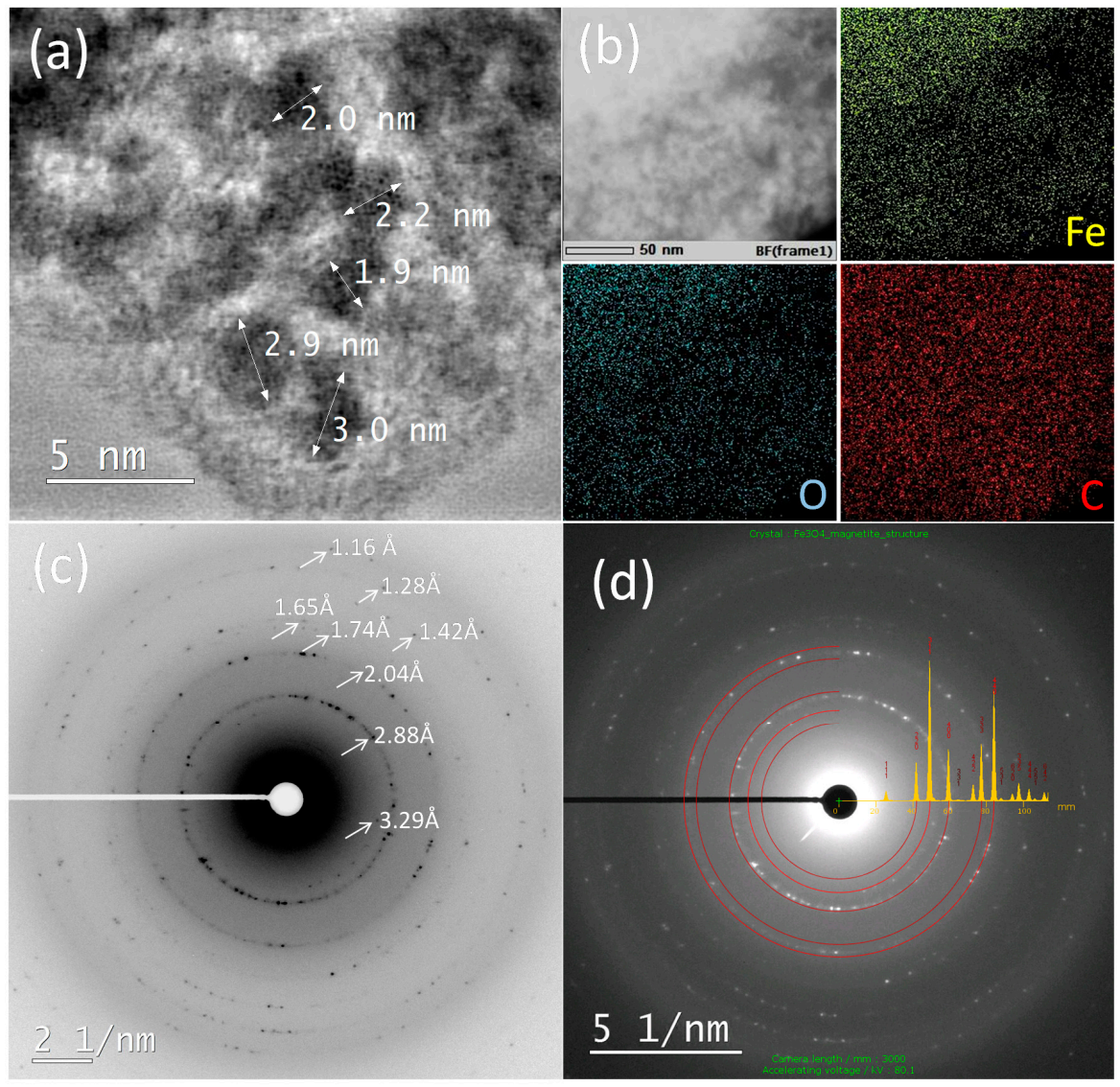

Figure 7. STEM bright-field image of the gel obtained at $130 \mathrm{kGy}$ from $20 \mathrm{wt} \% \mathrm{Fe}^{3+}$ suspension (a); EDXS elemental mapping of the gel where yellow, blue, and red colors represent iron $(\mathrm{Fe})$, oxygen $(\mathrm{O})$, and carbon (C), respectively (b); SAED (selected area electron diffraction) of spherical nanoparticles (NPs) with marked interplanar distances (c); SAED of spherical NPs indexed as magnetite $\left(\mathrm{Fe}_{3} \mathrm{O}_{4}\right)(\mathbf{d})$. 


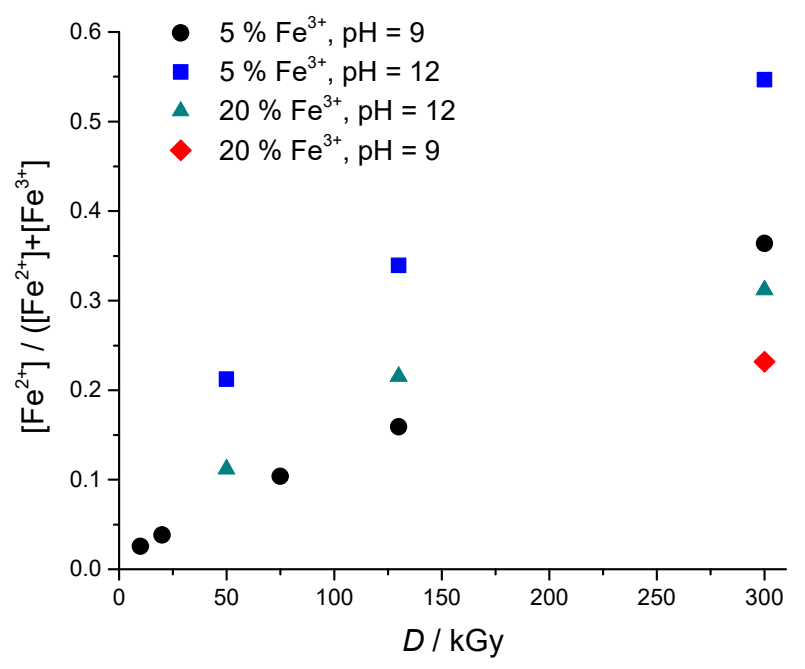

Figure 8. The $\mathrm{Fe}^{2+}$ fraction $\left(\left[\mathrm{Fe}^{2+} /\left(\mathrm{Fe}^{2+}+\mathrm{Fe}^{3+}\right)\right]\right)$ in relation to dose, $\mathrm{pH}$ and initial amount of $\mathrm{Fe}^{3+}$ in precursor suspensions as determined using the 1,10-phenanthroline UV-Vis spectrophotometric method. Samples were obtained from $1.85 \mathrm{wt} \%$ PEO precursor suspensions with 0.2 M 2-propanol.

The increase of 2-propanol concentration in initial suspensions to $0.8 \mathrm{M}$ did not result in the formation of gels, but in the formation of black magnetic suspensions. Figure 9 shows the XRD patterns and Mössbauer spectrum at room temperature of black magnetic powders isolated from suspensions obtained upon irradiation of $20 \mathrm{wt} \% \mathrm{Fe}^{3+}$ suspensions with $0.8 \mathrm{M}$ 2-propanol at $50 \mathrm{kGy}$ (Figure 9a) and at $130 \mathrm{kGy}$ (Figure 9b,c). These samples consist of magnetite with the volume-average domain size of approximately $3 \mathrm{~nm}$ in size (Table 1). The doublet in the Mössbauer spectrum, which can be assigned to small superparamagnetic maghemite (oxidized magnetite nanoparticles), is in accordance with XRD line broadening analysis $\left(D_{311}=3.2 \mathrm{~nm}\right)$.
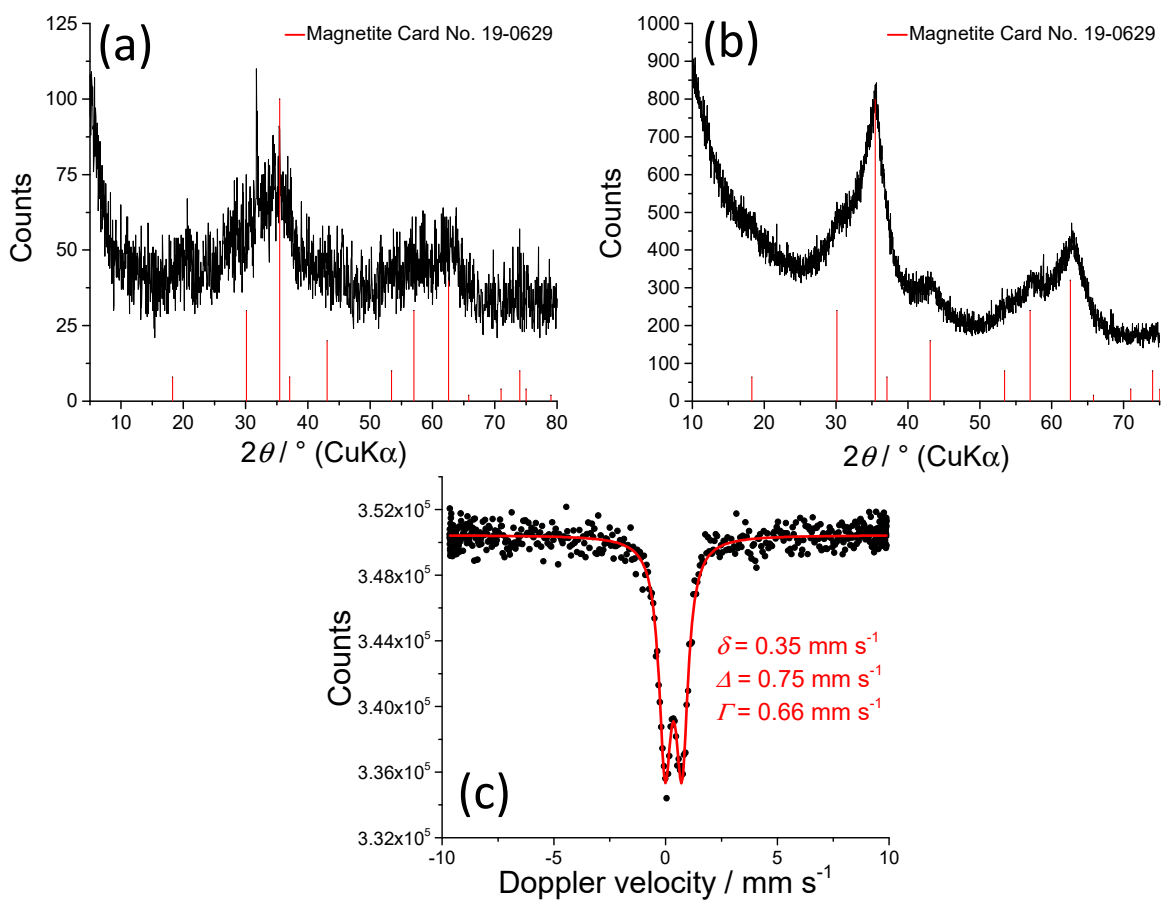

Figure 9. XRD patterns and Mössbauer spectrum at room temperature of PEO/Fe-oxide black magnetic powders obtained from $1.85 \mathrm{wt} \%$ PEO suspensions with $20 \mathrm{wt} \% \mathrm{Fe}^{3+}$ and four times more 2-propanol $(0.8 \mathrm{M})$ at $50 \mathrm{kGy}(\mathbf{a})$ and $130 \mathrm{kGy}(\mathbf{b}, \mathbf{c})$. 
As can be seen from the above results, a critical step in the one-step synthesis of magnetic iron oxide nanocomposite gels was to find a balance between the good reducing conditions required for the formation of magnetic particles and the conditions suitable for the formation of the polymer network. The permanent shape of wall-to-wall gels obtained on irradiation without 2-propanol is strong evidence of a three-dimensional network and PEO intermolecular crosslinking. It is known that on irradiation of dilute PEO aqueous solutions, the main mechanism for crosslinking of PEO chains is a reaction with hydroxyl radicals formed on water radiolysis (Equation (1)) [31,32,44]. If conditions are favorable (a relatively low dose rate and a diluted PEO concentration), owing to good mobility in dilute solutions, such formed PEO macroradicals preferably crosslink resulting in macrogel formation.

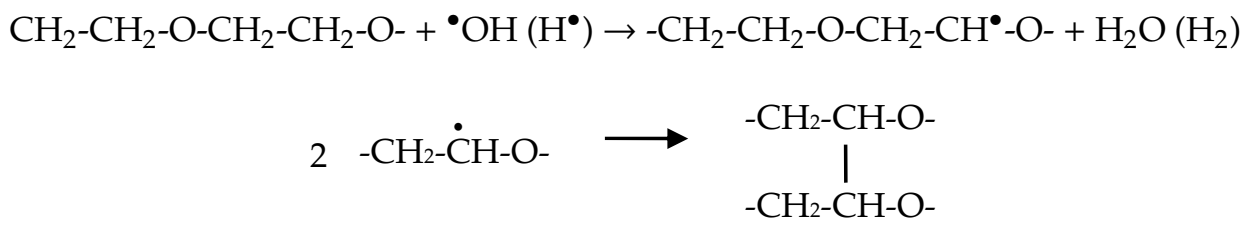

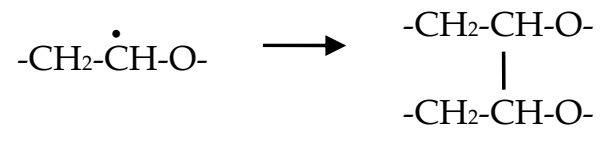

The precursor particles did not significantly disturb the intermolecular crosslinking of PEO chains. Although during the process of formation of $\mathrm{PEO}$ network, ${ }^{\bullet} \mathrm{OH}$ radicals, which are oxidizing agents, are partially removed from the system, the reducing conditions when irradiated without 2-propanol were still not strong enough to reduce the Fe(III) precursor nanoparticles. When 2-propanol in a concentration of $0.2 \mathrm{M}$ was added in a system to enhance reducing conditions, magnetite nanoparticles were formed (Figures 5-8). 2-propanol scavenges hydroxyl radicals which are oxidizing agents, and prevents back oxidation of formed ferrous ions

$$
\bullet \cdot \mathrm{OH}\left(\mathrm{H}^{\bullet}\right)+\left(\mathrm{CH}_{3}\right)_{2} \mathrm{CHOH} \rightarrow \mathrm{H}_{2} \mathrm{O}\left(\mathrm{H}_{2}\right)+\left(\mathrm{CH}_{3}\right)_{2} \mathrm{C}^{\bullet} \mathrm{OH}
$$

Thus formed 2-propanol radicals can act as additional reducing agent [45]:

$$
\mathrm{Fe}^{3+}+\left(\mathrm{CH}_{3}\right)_{2} \mathrm{C}^{\bullet} \mathrm{OH} \rightarrow \mathrm{Fe}^{2+}+\left(\mathrm{CH}_{3}\right)_{2} \mathrm{CO}+\mathrm{H}^{+}
$$

The addition of 2-propanol had a pronounced effect on the formation of PEO gels. Irradiation of pure PEO solutions with 2-propanol $(0.2 \mathrm{M})$ did not result in the formation of any gel content, even at $300 \mathrm{kGy}$. By scavenging the ${ }^{\bullet} \mathrm{OH}$ radicals, which are also initiators of PEO crosslinking, 2-propanol reduced the yield of PEO macroradicals, and hence the crosslinking degree. On the other hand, on irradiation of $\mathrm{PEO} / \mathrm{Fe}(\mathrm{III})$ precursor suspensions, magnetic gels were formed, and the amount of gel depended on the dose and initial amount of $\mathrm{Fe}^{3+}$ (Figure 2). This suggests that PEO chains are additionally crosslinked through formed iron oxide nanoparticles. An additional reason may lie in the possible contribution of iron oxide NPs to the formation of higher yield of hydroxyl radicals, like the one observed for nanosilica by Le Caër et al. [46]. They showed that on irradiation of the silica/water system, an exciton was formed that may be scavenged by water molecules and further react to produce additional hydroxyl radicals, protons, and hydrogen. Besides, the additional hydroxyl radicals may be formed in the Fenton reaction, because the $\mathrm{Fe}^{3+}$ that is reduced to $\mathrm{Fe}^{2+}$ by hydrated electrons may be reoxidized by radiolytically formed $\mathrm{H}_{2} \mathrm{O}_{2}$ thus producing additional ${ }^{\bullet} \mathrm{OH}$ radicals.

At higher 2-propanol concentrations $(0.8 \mathrm{M})$ there were not enough hydroxyl radicals left for the polymer to crosslink, resulting in the formation of highly magnetic magnetite NPs suspensions (Figure 8).

When more concentrated PEO suspensions $(4 \mathrm{wt} \%)$ pure or with various amount of $\mathrm{Fe}^{3+}$ were irradiated, black wall-to-wall hydrogels were obtained, similar to those obtained by irradiation without 2-propanol, probably due to the higher yield of PEO intermolecular crosslinking (photos in Figure 2).

Therefore, by finding the optimal conditions we were able to synthesize magnetic PEO/iron oxide nanocomposite gels in a single step. 


\subsection{Thermal Characterization of Gels}

The thermal properties of obtained nanocomposite gels in dependence on the $\gamma$-irradiation dose and the initial $\mathrm{Fe}^{3+}$ concentration were studied by differential scanning calorimetry. The DSC thermograms are given in Figure S2 in Supplementary Materials, while the phase transformation enthalpies and temperatures of the second heating and first cooling cycles are given in Figure 10, Figure 11, Figures S3 and S4. The results are presented in dependence on both the irradiation dose and the mass percentage of $\mathrm{Fe}^{3+}$ in precursor suspensions, as some effects are easier to observe. It must be emphasized again that when comparing the results of pure PEO gels with those of nanocomposites, one has to take into account that pure PEO gels were formed on irradiation without 2-propanol, because with 2-propanol in pure PEO solutions gels were not formed. Therefore, the difference between pure PEO gels and nanocomposite gels is not solely due to the amount of NPs within the gel, but also due to the influence of 2-propanol on network formation.

Enthalpies and temperatures of melting and crystallization decreased with the dose over the entire dose range for both pure PEO gels and PEO/iron oxide nanocomposite gels (Figure 10, Figure 11, Figures S3 and S4). At 300 kGy almost completely amorphous gels with a high degree of crosslinking were obtained, especially in the case of pure PEO gel and gel obtained from $20 \mathrm{wt} \% \mathrm{Fe}^{3+}$ suspension (Figure 10). At higher doses there is a higher yield of PEO intermolecular crosslinking; crosslinks are dense enough to significantly restrain mobility and impede crystallization of PEO chains on drying, which resulted in more amorphous gels. The smallest changes of enthalpies in dependence on dose were for gels with the highest NPs content (highest initial $\mathrm{Fe}^{3+}$ content) (Figure 10). The decrease of melting $\left(T_{\mathrm{m}}\right)$ and crystallization $\left(T_{\mathrm{c}}\right)$ temperatures with the dose was the most abrupt for pure PEO gels (Figure 11). A high density of crosslinks is the main reason for such low $T_{\mathrm{m}}$ and $T_{\mathrm{c}}$. Crosslinks increase the number of defects in the crystalline phase resulting in less "perfect" crystallites and consequently decrement in the melting temperature. Crosslinks also impose restrictions on molecular motions of PEO chains and at high doses the high density of PEO crosslinks and a small segment of PEO chains between two crosslink junctions seriously impede crystallizability, resulting in a significant lowering of $T_{\mathrm{c}}$. Such a decrease of $T_{\mathrm{m}}$ and enthalpies of melting with the dose for PEO gels was also reported by other authors $[12,30,47]$.

The increased amount of initial $\mathrm{Fe}^{3+}$ salt at the same dose led to the increased amount of formed gel with reduced enthalpies, suggesting the enhanced PEO crosslinking through formed Fe-oxide NPs (Figure 10 and Figure S4). In general, all nanocomposite gels at a certain dose had higher melting and crystallization temperatures than pure PEO gels (Figure 11). The amount of nanoparticles (initial Fe ${ }^{3+}$ content) at a certain dose had a significant effect on enthalpies decrease, but very little impact on temperatures (Figure 10). While there was approximately a $20^{\circ} \mathrm{C}$ jump in $T_{\mathrm{m}}$ and $T_{\mathrm{c}}$ for gel obtained from $1 \% \mathrm{Fe}^{3+}$ suspension compared to pure PEO gels at the certain dose, the further increase of initial $\mathrm{Fe}^{3+}$ to $20 \%$ resulted in a higher amount of formed gels with lower enthalpies but only slightly lower $T_{\mathrm{c}}$ and $T_{\mathrm{m}}$. A similar trend in temperature changes with the increase of silica NPs we observed in our previous work [12].

The observed change in the melting enthalpies and temperatures with the NPs content can be explained by the impact of NPs. NPs can act as nucleating agents-they induce heterogeneous crystallization centers and thus facilitate crystallization of uncrosslinked PEO segments and increase $T_{\mathrm{c}}$ [48]. On the other hand, at high NPs concentration, due to worsened dispersion and partial NPs agglomeration, NPs can restrain the mobility of partially crosslinked PEO chains and its crystallizability. At the same time, agglomerates can be a serious obstacle for PEO crosslinking. Since in composites obtained with 2-propanol, more gel was formed with initial $\mathrm{Fe}^{3+}$ increase, the main reason for the decrease in enthalpies is obviously the additional crosslinking of PEO chains by NPs. So, while pure PEO gels are formed by intermolecular crosslinking of PEO chains, in nanocomposites some type of interactions/bonding between Fe-oxide NPs and PEO chains such as H-bonds or coordination bonding [49-51] are likely to contribute to the radiation-induced crosslinking of PEO chains, resulting in further amorphization. The highest dose dependence of enthalpies and temperatures for pure PEO 
gels support the above conclusion. The interactions of $\mathrm{Fe}_{2} \mathrm{O}_{3}$ and $\mathrm{TiO}_{2}$ particles and polymer have been observed observed by Popescu et al. [52], whereas Davenas et al. [53] noted that silica filler can act as an additional crosslinker that upon irradiation formed covalent bonds to the polymer matrix. Similarly, Agrawal et al. [54] observed laponite nanoparticles acting as additional junction points in physically associative PLA-PEO-PLA gel. Criado-Gonzalez et al. [55] and Peng at al. [56] observed the formation of a weak network due to crosslinking through coordination bonding of Fe(III) cations with alginate chains and PAA chains, respectively.

The role of NPs as nucleating agents can also be inferred from the behavior of gels obtained without 2-propanol. For nanocomposite gels prepared without 2-propanol the sole effect of nanoparticle content can be observed compared to the pure PEO gels (Figure 10, Figure 11and Figure S4).

The pure PEO gels and nanocomposite gels prepared from $4 \mathrm{wt} \%$ PEO suspensions had higher melting and crystallization enthalpies and temperatures than those obtained from $1.85 \mathrm{wt} \%$ PEO solutions at the same dose (Figure 10 and Figure S3). For pure PEO gels exactly the opposite would be expected; that irradiation of a more concentrated polymer solution would result in a higher crosslinks density and a more amorphous gel. The phase transformation temperatures of nanocomposite gels containing the same NPs content did not depend on PEO concentration, they were almost the same for 1.85 and $4 \mathrm{wt} \%$ suspensions.
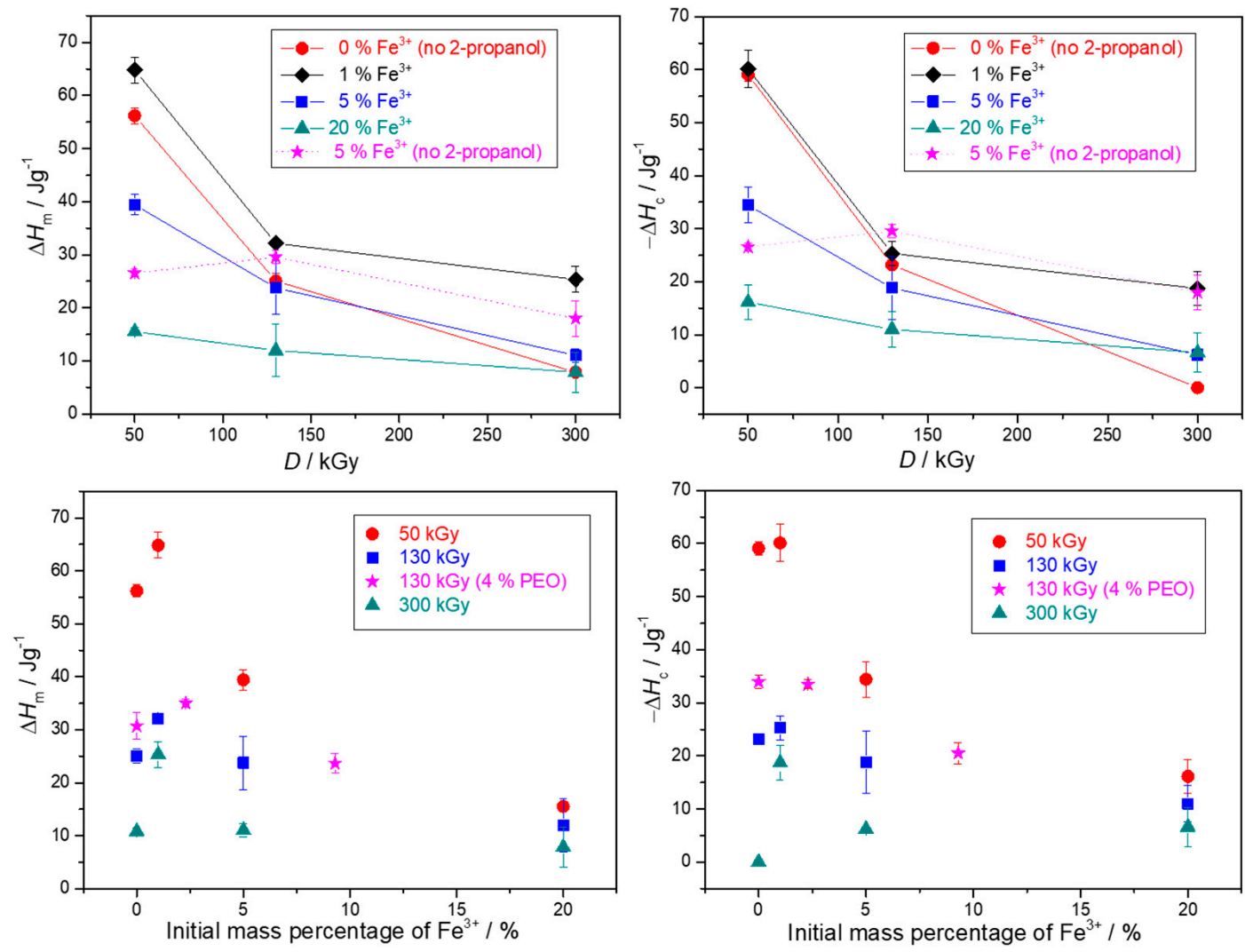

Figure 10. Melting $\left(\Delta H_{\mathrm{m}}\right)$ and crystallization $\left(\Delta H_{\mathrm{c}}\right)$ enthalpies of the 2 nd heating cycles and 1st cooling cycles, respectively, of the obtained gels in dependence on the irradiation dose and the mass percentage of $\mathrm{Fe}^{3+}$ in precursor suspensions. Unless otherwise indicated, the precursor suspensions were prepared from $1.85 \mathrm{wt} \%$ PEO solutions and with $0.2 \mathrm{M}$ 2-propanol. Mass percentage of $\mathrm{Fe}^{3+}$ of 1, 5, $20 \mathrm{wt} \%$ (relative to total PEO and $\mathrm{Fe}^{3+}$ mass) in the precursor suspensions correspond to concentrations of $\mathrm{Fe}^{3+}$ ions of $0.35 \times 10^{-2} \mathrm{M}, 1.75 \times 10^{-2} \mathrm{M}$, and $7 \times 10^{-2} \mathrm{M}$ in the case of $1.85 \mathrm{wt} \%$ PEO suspensions. In the case of $4 \mathrm{wt} \%$ PEO suspensions, $\mathrm{Fe}^{3+}$ concentrations of $1.75 \times 10^{-2} \mathrm{M}$ and $7 \times 10^{-2} \mathrm{M}$ correspond to 2.3 and $9.3 \mathrm{wt} \% \mathrm{Fe}^{3+}$. 

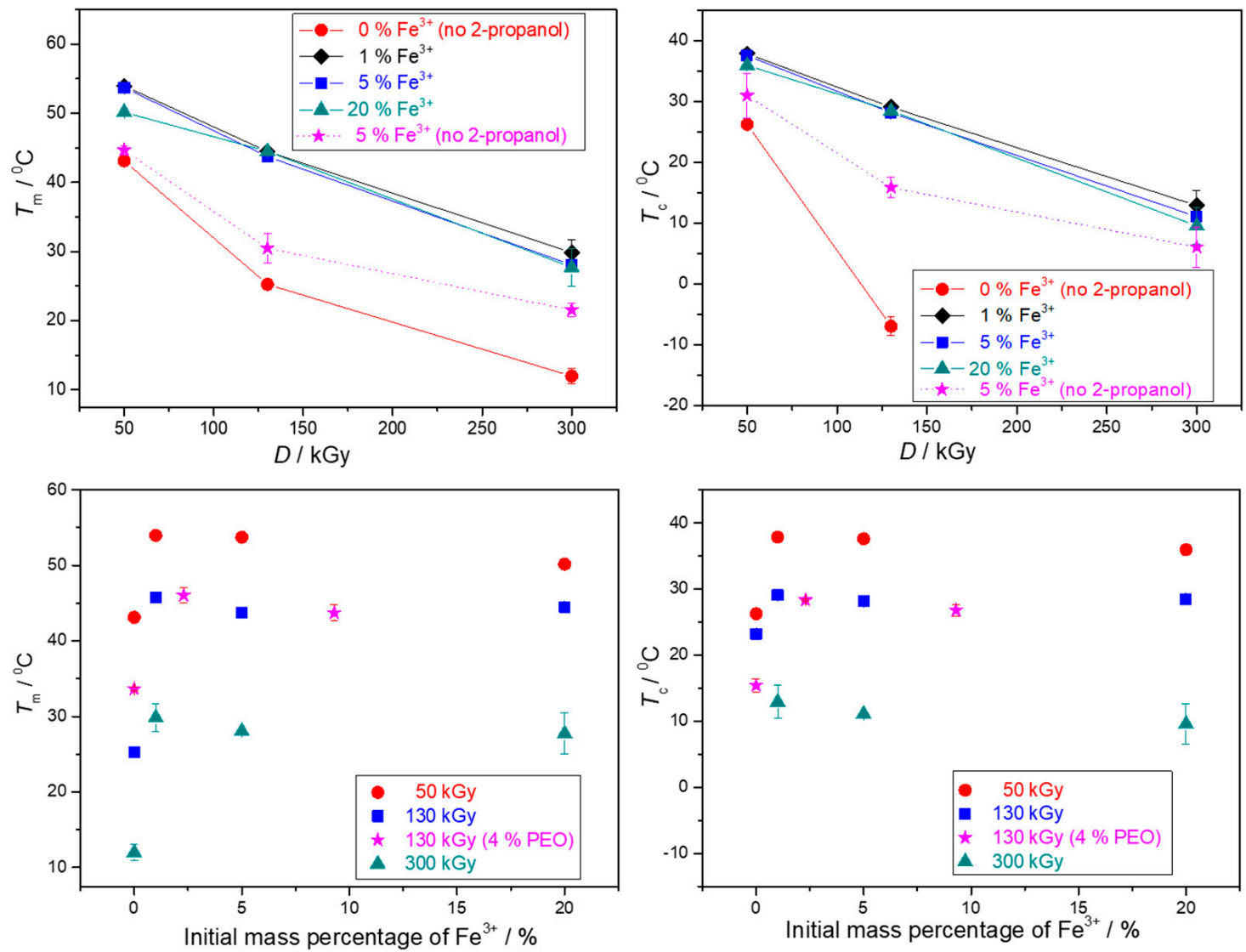

Figure 11. Melting $\left(T_{\mathrm{m}}\right)$ and crystallization $\left(T_{\mathrm{c}}\right)$ temperatures of the 2nd heating cycles and 1st cooling cycles, respectively, of the obtained gels in dependence on the irradiation dose and the mass percentage of $\mathrm{Fe}^{3+}$ in precursor suspensions. Unless otherwise indicated, the precursor suspensions were prepared from $1.85 \mathrm{wt} \%$ PEO solutions and with $0.2 \mathrm{M}$ 2-propanol.

\subsection{Rheological Properties of Gels}

The rheological properties of the gels were investigated at different conditions within the linear viscoelastic region (LVR).

The amplitude sweep test at room temperature for gels obtained at various doses starting from $1.85 \mathrm{wt} \%$ PEO precursor suspensions is presented in Figure 12a,b,c and Figure S5 in Supplementary Materials and the values are given in Table 2. All investigated gels behave like viscoelastic solids with $G^{\prime}$ values (storage modulus) higher than $G^{\prime \prime}$ values (loss modulus), confirming a well-ordered gel network [57]. Storage moduli (as well as yield and flow point) increased with the irradiation dose for both pure PEO gels and all nanocomposite gels indicating higher network density. Slightly stiffer gels were formed at higher dose. The increase of the storage modulus $G^{\prime}$ and crosslink density with the irradiation dose has been observed for different radiation crosslinked gels, like PEO [58] and PVP hydrogels [59]. All nanocomposite gels had higher storage moduli, yield points and flow points compared to pure PEO gels at a certain dose. Generally, at a particular dose, storage moduli, yield point and flow point increased with the increase of $\mathrm{Fe}^{3+}$ content in precursor suspensions. At 50 and $130 \mathrm{kGy}$ storage moduli increased with initial $\mathrm{Fe}^{3+}$ content, while at $300 \mathrm{kGy}$ there was an extreme increase for gel prepared from $5 \mathrm{wt} \% \mathrm{Fe}^{3+}$ suspension compared to pure PEO gel but no further increase for gel prepared from $20 \mathrm{wt} \% \mathrm{Fe}^{3+}$ suspension. The quantity loss factor, $\tan (\delta)=G^{\prime \prime} / G^{\prime}$, determines the relative elasticity of viscoelastic materials. The gels with a value of $\tan (\delta)=0.1$ and lower belong to stiff gels and are indicative of well-ordered systems. For $50 \mathrm{kGy}$ loss factor value was low for pure PEO (0.01) compared to gels prepared from $5 \%(0.11)$ and $20 \%(0.08) \mathrm{Fe}^{3+}$ suspensions, meaning that pure PEO has a better ordered microstructure of the gel compared to nanocomposites. At $130 \mathrm{kGy}$ the 
values of storage modulus, the yield, and flow points of gel obtained at $20 \%$ initial $\mathrm{Fe}^{3+}$ content were 2 to 4 times higher than for gel from initial $5 \mathrm{wt} \% \mathrm{Fe}^{3+}$ and pure $\mathrm{PEO}$, respectively, but the loss factor values of these gels were similar. The gel obtained from suspensions with the highest $\mathrm{Fe}^{3+}$ content $(20 \%)$ at $300 \mathrm{kGy}$ showed the longest yielding zone (the zone between yield point and flow point) through a range of $700 \mathrm{~Pa}$ indicating very stiff structure.
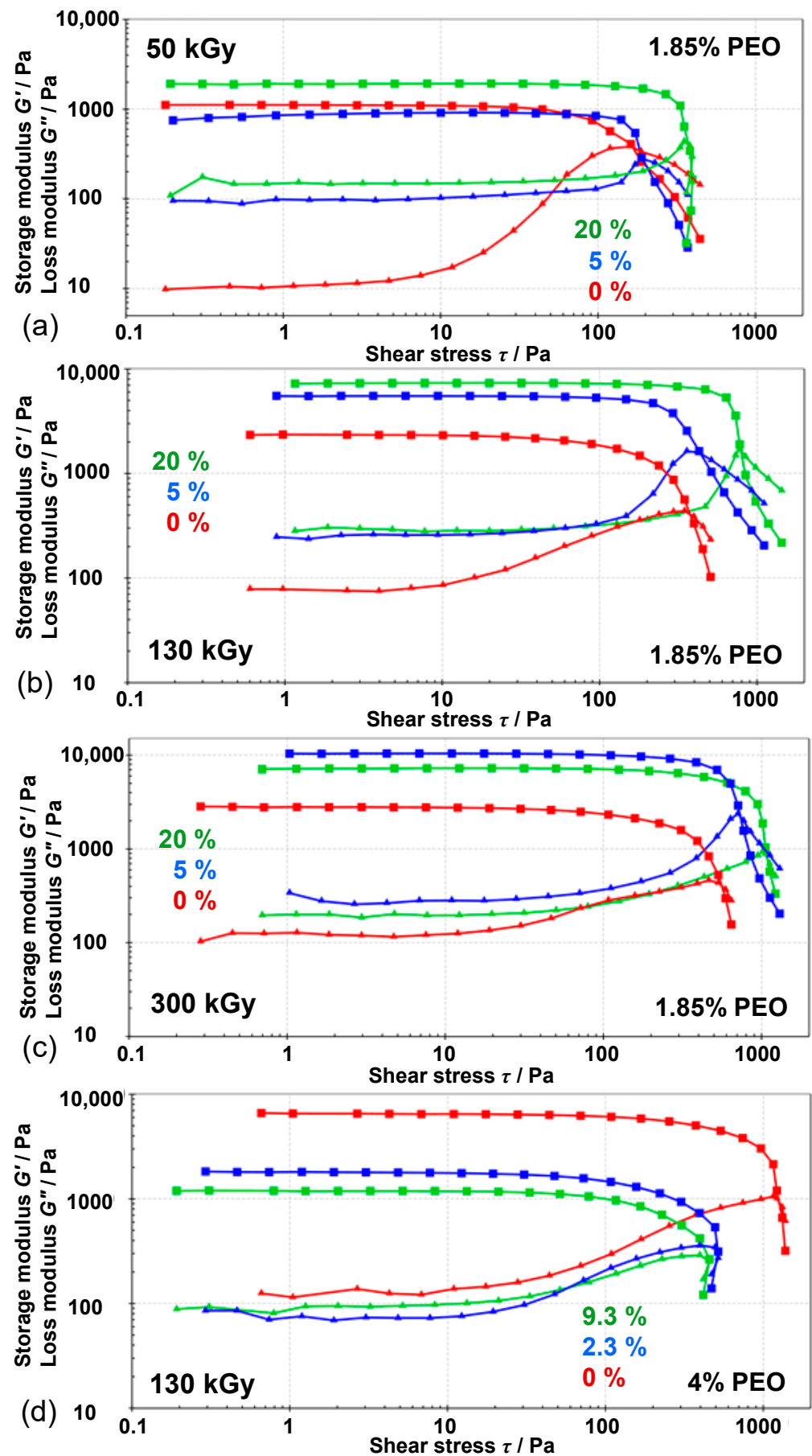

Figure 12. Amplitude sweep test $\left(G^{\prime}(\mathbf{\square})\right.$ and $G^{\prime \prime}(\boldsymbol{\Lambda})$ values) of pure PEO gels and nanocomposite gels obtained at (a) $50 \mathrm{kGy}$, (b) $130 \mathrm{kGy}$, and (c) $300 \mathrm{kGy}$ from $1.85 \mathrm{wt} \%$ PEO suspensions, and at (d) $130 \mathrm{kGy}$ from $4.0 \mathrm{wt} \%$ PEO suspensions, at $25^{\circ} \mathrm{C}$. The initial mass percentage of $\mathrm{Fe}^{3+}$ (relative to the total PEO and $\mathrm{Fe}^{3+}$ mass) in precursor suspensions is indicated. 
Table 2. Results of amplitude sweep test of pure PEO gels and PEO/Fe-oxide nanocomposite gels.

\begin{tabular}{ccccccc}
\hline $\begin{array}{c}\text { Initial Mass } \\
\text { Percentage } \\
\text { of } \mathbf{F e}^{3+* / \%}\end{array}$ & $\begin{array}{c}\text { Mass Percentage } \\
\text { of PEO Aqueous } \\
\text { Solution/\% }\end{array}$ & $\mathbf{D} / \mathbf{k G y}$ & $\begin{array}{c}\boldsymbol{G}^{\prime} \\
(\mathbf{M a x}) / \mathbf{P a}\end{array}$ & $\begin{array}{c}\text { Yield } \\
\text { Point/Pa }\end{array}$ & $\begin{array}{c}\text { Flow } \\
\text { Point/Pa }\end{array}$ & $\begin{array}{c}\text { Loss Factor } \\
(\tan \delta= \\
\left.\mathbf{G}^{\prime \prime} / G^{\prime}\right)\end{array}$ \\
\hline 0 & 1.85 & 50 & 816 & 56.0 & 166.3 & 0.01 \\
5 & 1.85 & 50 & 1115 & 117.4 & 192 & 0.11 \\
20 & 1.85 & 50 & 1907 & 192.8 & 375 & 0.08 \\
0 & 1.85 & 130 & 2336 & 98.5 & 377.3 & 0.04 \\
5 & 1.85 & 130 & 5519 & 201.9 & 439.2 & 0.05 \\
20 & 1.85 & 130 & 7300 & 455.3 & 788.3 & 0.04 \\
0 & 1.85 & 300 & 2784 & 124.2 & 559.7 & 0.04 \\
5 & 1.85 & 300 & 10,325 & 386.3 & 736.3 & 0.03 \\
20 & 1.85 & 300 & 7220 & 355.0 & 1086 & 0.03 \\
0 & 4 & 130 & 6507 & 298.6 & 1261 & 0.03 \\
$2.3^{* *}$ & 4 & 130 & 1800 & 82.4 & 517.4 & 0.05 \\
$9.3^{* *}$ & 4 & 130 & 1200 & 72.8 & 450.2 & 0.09 \\
\hline
\end{tabular}

Pure PEO gels were prepared by irradiation without the addition of 2-propanol. * Initial $\mathrm{wt} \%$ of $\mathrm{Fe}^{3+}$ relative to the total mass of $\mathrm{PEO}$ and $\mathrm{Fe}^{3+}$ in precursor suspensions. ${ }^{* *} 4 \mathrm{wt} \% \mathrm{PEO}$ suspensions had the same initial concentration of $\mathrm{Fe}^{3+}$ salt as in $1.85 \mathrm{wt} \% \mathrm{PEO}$, i.e., suspensions contained $\sim 2 \mathrm{x}$ more $\mathrm{PEO}$ but the same amount of $\mathrm{Fe}^{3+}$, resulting in 2.3 and $9.3 \mathrm{wt} \%$ of $\mathrm{Fe}^{3+}$ relative to the total $\mathrm{PEO}$ and $\mathrm{Fe}^{3+}$ mass.

The results show that a higher degree of intermolecular crosslinking with increased dose increases the storage modulus and the gel becomes stiffer. But pure PEO with a high degree of exclusively intermolecular PEO crosslinking was still softer than nanocomposite gels. The increase in elastic moduli, flow, and yield points of nanocomposite gels and the formation of stronger gels confirms a well-ordered gel network, well-ordered microstructure and indicates good NPs dispersion. This increase is not only due to the reinforcing effect of inorganic NPs, but the formed magnetic NPs facilitate the formation of gels by acting as additional crosslinkers. Similarly, Agrawal et al. [54] found that $G^{\prime}$ of PLA-PEO-PLA gel increased dramatically when the amount of laponite particles was increased, indicating the formation of new junctions by the nanoparticles. Blyakhman et al. [1] reported the increase in Young's modulus of PAAm gel resulting from the addition of a low concentration of magnetic NPs, reflecting the direct effect of magnetic NPs on gel elasticity, and reported the possibility that MNPs act as crosslinking agents.

All this is consistent with the decrease in enthalpies and temperatures of these gels with increasing dose and $\mathrm{Fe}^{3+}$ content, as observed from DSC measurements. In addition, the similar values of $G^{\prime}$ of $20 \%$ compared to $5 \%$ gels at $300 \mathrm{kGy}$ (in line with the similar melting enthalpies) (Figure 12 and Figure S5) may be due to the likely agglomeration of NPs at high NPs content.

The amplitude sweep test of gels obtained at $130 \mathrm{kGy}$ from $4 \mathrm{wt} \%$ PEO precursor suspensions showed the opposite behavior depending on the initial $\mathrm{Fe}^{3+}$ content (Figure 12d) to gels obtained from $1.85 \mathrm{wt} \%$ PEO suspensions. The gels obtained from $4 \mathrm{wt} \%$ PEO suspensions had the same initial concentration of $\mathrm{Fe}^{3+}$ salt as in $1.85 \mathrm{wt} \%$ PEO (resulting in 2.3 and $9.3 \mathrm{wt} \% \mathrm{Fe}^{3+}$ relative to the total initial mass of $\mathrm{PEO}$ and $\mathrm{Fe}^{3+}$ ). The pure PEO gel obtained from $4 \mathrm{wt} \% \mathrm{PEO}$ was by far the strongest by all parameters, while the gel with the highest NPs content was the weakest. $G^{\prime}$ values, yield point and flow point were in descending order with increasing initial $\mathrm{Fe}^{3+}$ amount, while the loss factor $(\tan \delta)$ increased. As expected, stronger gels can be obtained by increasing the polymer concentration in the starting suspension, resulting in a higher density of the network formed by intermolecular crosslinking. But the effect of NPs did not show an improved behavior as in the case of lower polymer concentration. Obviously, at higher polymer concentration the effect of intermolecular crosslinking of PEO chains is dominant over crosslinking through Fe-oxide NPs.

Figure 13 presents the frequency sweep measurements. Frequency sweeps describe the time-dependent behavior of a sample in the non-destructive deformation range. The investigated samples are true chemically crosslinked gels. The frequency sweep of pure PEO and magnetic nanocomposite gels showed constant storage modulus $\left(G^{\prime}\right)$ values within the entire frequency range 
(100 rad/s to $0.05 \mathrm{rad} / \mathrm{s})$. Pure PEO and PEO/Fe-oxide gels showed similar behavior at lower frequencies, but at higher frequencies, pure PEO gel obtained more ordered structure, better homogeneity (lower loss factor) compared to nanocomposite gels with higher loss factor values (because of increase of loss modulus at higher frequences). The same remarks related to internal gel microstructure have been seen for pure PEO gels and nanocomposites at different doses except for gels from $4 \mathrm{wt} \%$ of PEO.
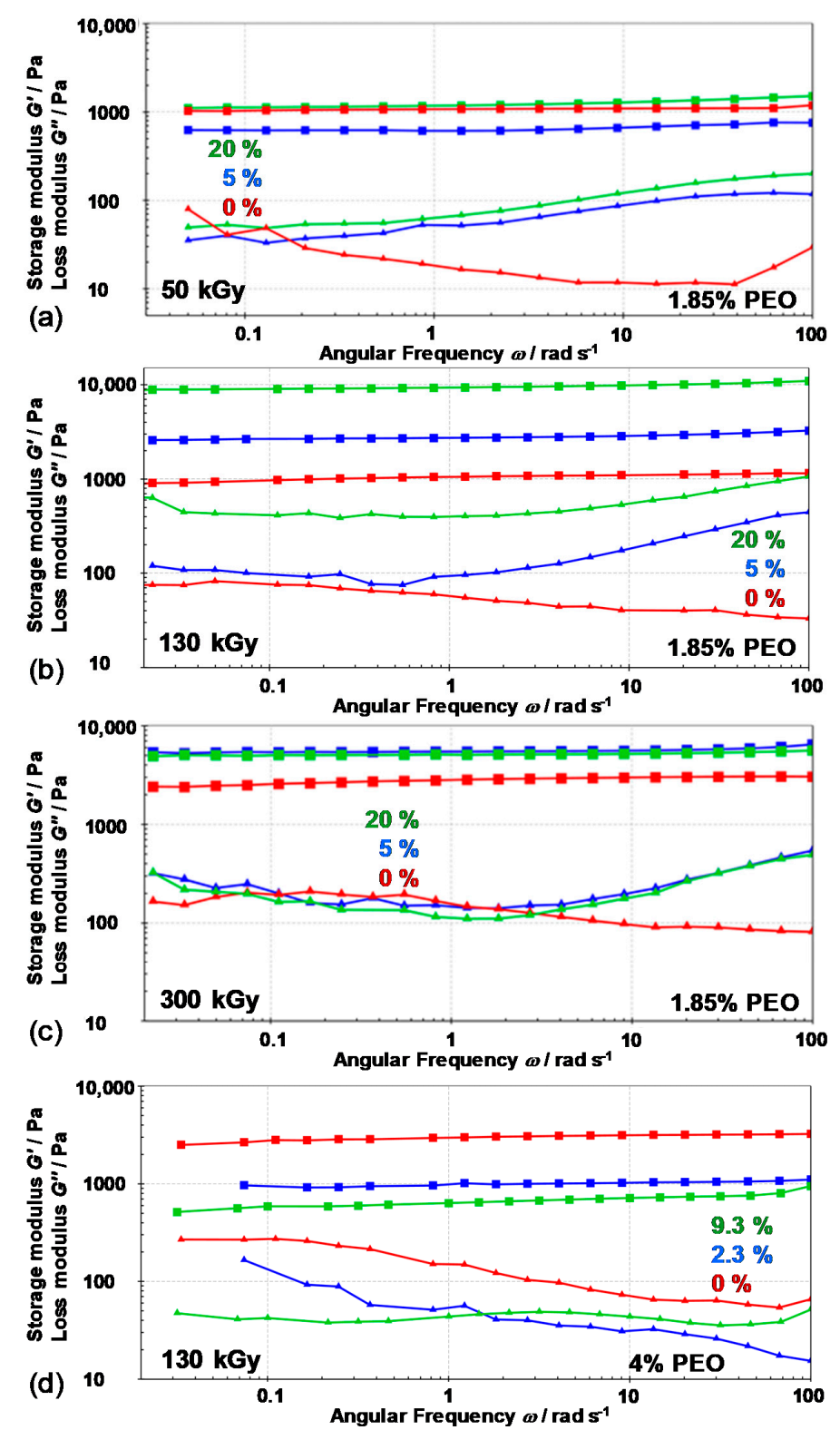

Figure 13. Frequency sweep tests $\left(G^{\prime}(\mathbf{\square})\right.$ and $G^{\prime \prime}(\mathbf{\Lambda})$ values) of pure PEO gels and nanocomposite gels obtained at (a) $50 \mathrm{kGy}$, (b) $130 \mathrm{kGy}$, and (c) $300 \mathrm{kGy}$ from $1.85 \mathrm{wt} \%$ PEO suspensions, and at (d) $130 \mathrm{kGy}$ from $4.0 \mathrm{wt} \%$ PEO suspensions, at $25^{\circ} \mathrm{C}$. Initial mass percentage of $\mathrm{Fe}^{3+}$ in precursor suspensions is indicated.

Results of 3ITT thixotropy test are given in Figure 14 and Figure S6. Thixotropy is a time-dependent phenomenon. It can be defined as the shear thinning behavior of a viscoelastic gel sample upon the application of a destructive strain and the subsequent recovery of the viscoelastic properties after cessation of the strain. Figure 14 shows the evaluation of complex viscosity and Figure $\mathrm{S} 6$ the evolution of $G^{\prime}$ and $G^{\prime \prime}$ of gels after applying the destructive strain. The sample behavior switched from gel-like to sol-like, with $G^{\prime \prime}$ values higher than $G^{\prime}$. After that, the original conditions reapplied and the recovery 
of viscoelastic properties of gels was observed. Recovery ratios of gels within $60 \mathrm{~s}$ are given in Table 3 . The initial $\mathrm{Fe}^{3+}$ amount, that is the amount of NPs formed, and the density of the PEO network formed at a specific $\gamma$-irradiation dose influenced the self-recoverable properties of the new nanocomposite materials. The most prominent recovery of the viscoelastic properties was observed for gels from $1.85 \mathrm{wt} \%$ PEO suspensions at $50 \mathrm{kGy}$ and gels from $4 \mathrm{wt} \%$ PEO suspensions at $130 \mathrm{kGy}$ (Table 3). The recovery of pure PEO gel at the specific irradiation dose was always better compared to the nanocomposite gels (indicating very good microstructure integrity of pure PEO gel), except for gels obtained from $4 \mathrm{wt} \%$ PEO suspensions. The lowest recovery was observed for gel obtained at $300 \mathrm{kGy}$ from $20 \% \mathrm{Fe}^{3+}$ suspension (57.1\% recovery in $60 \mathrm{~s}$ ). Better recovery was observed for all gel samples with lower $G^{\prime}$ values compared to the recoverable properties of the most potent gels.

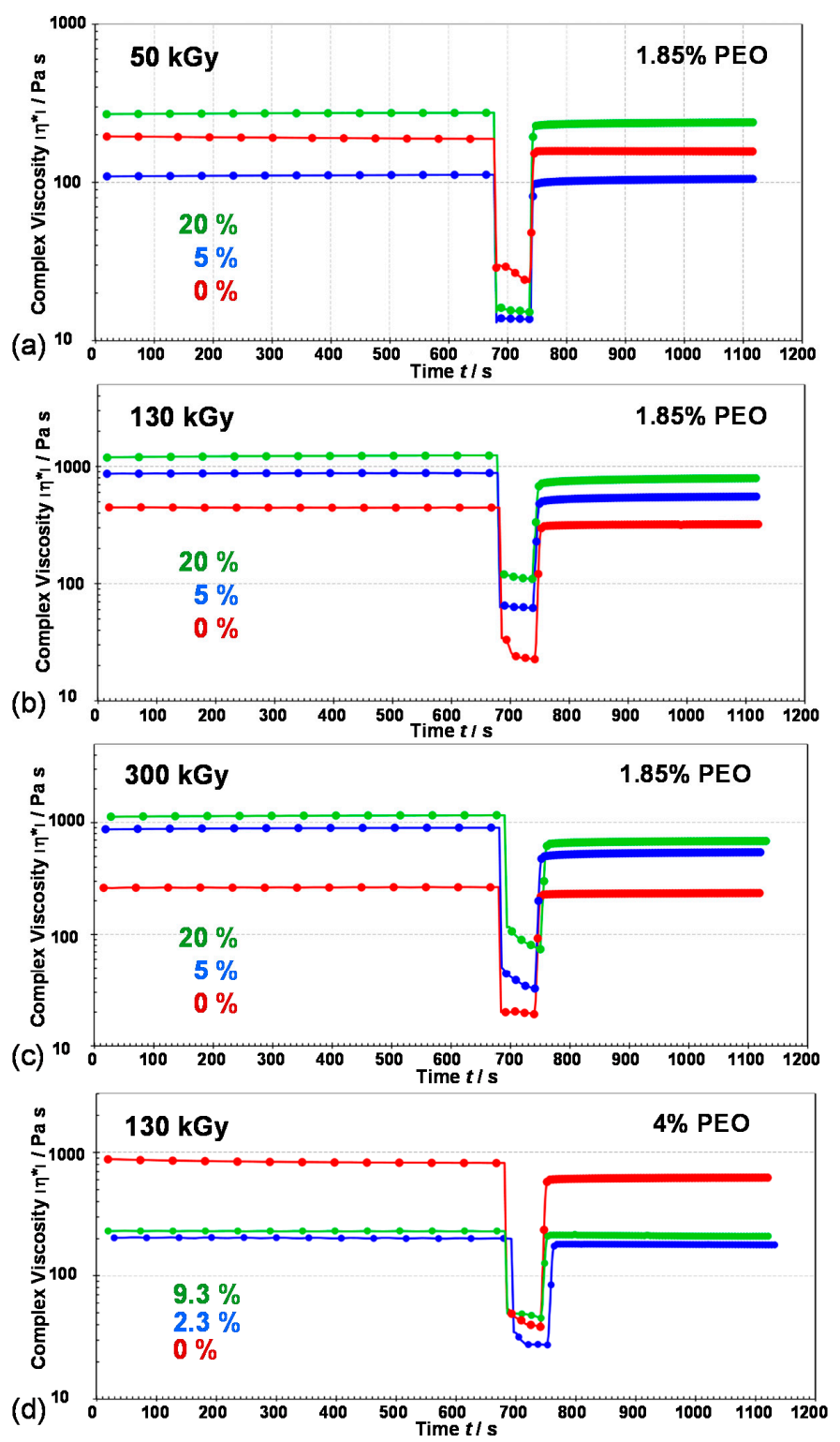

Figure 14. 3-interval thixotropy test (3ITT) of pure PEO gel and nanocomposite gels obtained at (a) $50 \mathrm{kGy}$, (b) $130 \mathrm{kGy}$, (c) $300 \mathrm{kGy}$ from $1.85 \mathrm{wt} \%$ PEO suspensions and (d) from $4 \mathrm{wt} \%$ PEO suspensions at $130 \mathrm{kGy}$ showed complex viscosity $\left(\eta^{*}\right)$ as a function of time and application of different strains (LVR-DR-LVR) at $25^{\circ} \mathrm{C}$. Linear viscoelastic region (LVR): strain $=0.1 \%$, frequency $=5 \mathrm{~Hz}$; destructive region (DR): strain $=300 \%$, frequency $=5 \mathrm{~Hz}$. Initial mass percentage of $\mathrm{Fe}^{3+}$ in precursor suspensions is indicated. 
Table 3. Self-recoverable properties of pure PEO gels and nanocomposite gels obtained at various doses and compositions of precursor suspensions determined in 3-interval thixotropy test.

\begin{tabular}{|c|c|c|c|c|c|c|c|c|c|c|c|c|}
\hline$w t^{2} \mathrm{Fe}^{3+}$ & 0 & 5 & 20 & 0 & 5 & 20 & 0 & 5 & 20 & 0 & 2.3 & 9.3 \\
\hline wt $\%$ PEO & 1.85 & 1.85 & 1.85 & 1.85 & 1.85 & 1.85 & 1.85 & 1.85 & 1.85 & 4.0 & 4.0 & 4.0 \\
\hline $\begin{array}{c}\text { Dose (kGy) } \\
\text { Recovery }\end{array}$ & 50 & 50 & 50 & 130 & 130 & 130 & 300 & 300 & 300 & 130 & 130 & 130 \\
\hline $\begin{array}{l}\text { 3ITT test (\%) } \\
\quad t=60 \mathrm{~s}\end{array}$ & 96.1 & 90.7 & 84.7 & 70.8 & 59.7 & 60.5 & 87.0 & 57.6 & 57.1 & 74.6 & 90.4 & 92.6 \\
\hline
\end{tabular}

The obtained magnetic PEO/iron oxide nanocomposite gels showed promising rheological properties for potential application in tissue engineering and as wound dressings. By further optimization of the system and irradiation conditions, magnetic gels with tailored properties for a particular application could be synthesized.

\section{Conclusions}

$\gamma$-irradiation proved to be a suitable method for the one-step synthesis of magnetic PEO/iron oxide nanocomposite hydrogels. For the one-step irradiation synthesis of magnetic PEO/iron oxide hydrogels the appropriate balance between conditions suitable for polymer crosslinking and conditions suitable for the reduction of Fe(III)-precursor was crucial.

$\gamma$-irradiation generated $\mathrm{Fe}^{2+}$ was quantitatively determined using the 1,10-phenanthroline UV-Vis spectrophotometric method. A maximum $\mathrm{Fe}^{2+}$ mole fraction of $55 \%$ was achieved at a dose of $300 \mathrm{kGy}$ and with $5 \mathrm{wt} \%$ of the initially added $\mathrm{Fe}^{3+}$ at $\mathrm{pH} \sim 12$.

The thermal, viscoelastic, and magnetic properties of the gels depended on the irradiation dose, and the PEO and initial $\mathrm{Fe}^{3+}$ concentration, i.e., amount of magnetic iron oxide NPs inside the gels. Stronger gels were formed at the higher dose and higher magnetite NPs content (in the case of $1.85 \mathrm{wt} \%$ PEO).

Both rheological measurements and DSC results suggested that the pronounced increase in strength and stiffness of nanocomposite gels was not only due to the reinforcing effect caused by the presence of iron oxide NPs, but that the formed magnetic iron oxide nanoparticles acted as additional crosslinkers of the PEO chains, thus facilitating the formation of potent gels.

At higher PEO concentrations ( $4 \mathrm{wt} \%$ ), the effect of intermolecular crosslinking of PEO chains was dominant over the effect of Fe-oxide NPs.

$\gamma$-irradiation of aqueous suspensions containing $\mathrm{PEO}, \mathrm{Fe}^{3+}$, and 2-propanol in alkali offered a possibility to obtain magnetic PEO/iron oxide nanocomposite gels with low crystallinity and improved strength.

By further optimization of the system and irradiation conditions ( $\mathrm{pH}$, polymer molecular mass, polymer and precursor concentration, as well as dose and dose rate) magnetic gels with tailored properties for a specific application could be synthesized.

Supplementary Materials: The following are available online at http://www.mdpi.com/2079-4991/10/9/1823/s1, Figure S1: The room temperature Mössbauer spectra of $\mathrm{PEO} / \mathrm{Fe}-$ oxide gels obtained from suspensions with: (a) $5 \mathrm{wt} \% \mathrm{Fe}^{3+}$ at $130 \mathrm{kGy}$; (b) $20 \mathrm{wt} \% \mathrm{Fe}^{3+}$ at $130 \mathrm{kGy}$; (c) $5 \mathrm{wt} \% \mathrm{Fe}^{3+}$ at $300 \mathrm{kGy}$; (d) $20 \mathrm{wt} \% \mathrm{Fe}^{3+}$ at $300 \mathrm{kGy}$. All precursor suspensions were prepared from $1.85 \mathrm{wt} \%$ PEO solutions and with $0.2 \mathrm{M}$ 2-propanol. Mössbauer parameters are given: $\delta=$ isomer shift relative to $\alpha$-Fe at $20^{\circ} \mathrm{C} ; \Delta=$ quadrupole splitting; $\Gamma=$ line width. Error: $\delta= \pm 0.01 \mathrm{~mm} \mathrm{~s}^{-1} ; \Delta= \pm 0.01 \mathrm{~mm} \mathrm{~s}^{-1}$, Figure S2: DSC thermographs of the 2nd heating $(\mathrm{a}, \mathrm{b})$ and the 1 st cooling $(\mathrm{c}, \mathrm{d})$ cycles of pure PEO gel and nanocomposite gels obtained at 50, 130 and $300 \mathrm{kGy}$ from $1.85 \mathrm{wt} \%$ PEO precursor suspensions with various $\mathrm{Fe}^{3+}$ content. Unless otherwise indicated, suspensions contained 0.2 M 2-propanol, Figure S3: Melting enthalpies and temperatures of the 1st heating cycles of the obtained gels in dependence on the irradiation dose and the mass percentage of $\mathrm{Fe}^{3+}$ in precursor suspensions. Unless otherwise indicated, the precursor suspensions were prepared from $1.85 \mathrm{wt} \%$ PEO solutions and with addition of $0.2 \mathrm{M} 2$-propanol. All gels obtained at $300 \mathrm{kGy}$ with 2-propanol, and pure PEO gel at $130 \mathrm{kGy}$, were totally amorphous in the first heating cycle (no melting enthalpies). Gels obtained by irradiation from $5 \mathrm{wt} \% \mathrm{Fe}^{3+}$ suspensions without 2-propanol had two melting maxima (both are given on graph), Figure S4: Melting $\left(\Delta H_{\mathrm{m}}\right)$ and crystallization 
$\left(\Delta H_{\mathrm{m}}\right)$ enthalpies and temperatures $\left(T_{\mathrm{m}}\right.$ and $\left.T_{\mathrm{c}}\right)$ of the 2 nd heating cycles and the 1st cooling cycles, respectively, of gels obtained at various doses in dependence on the mass percentage of $\mathrm{Fe}^{3+}$ in $1.85 \mathrm{wt} \%$ PEO precursor suspensions. Unless otherwise indicated suspensions contained 0.2 M 2-propanol, Figure S5: Comparison of amplitude sweep test $\left(G^{\prime}(\boldsymbol{\square})\right.$ and $G^{\prime \prime}(\boldsymbol{\Lambda})$ values) of nanocomposite gels obtained at $130 \mathrm{kGy}$ and $300 \mathrm{kGy}(1.85 \mathrm{wt} \%$ PEO solution), at $25^{\circ} \mathrm{C}$. Initial mass percentage of $\mathrm{Fe}^{3+}$ in precursor suspensions is indicated, Figure S6: 3-interval thixotropy test (3ITT) (storage $G^{\prime}(\mathbf{\square})$ and loss $G^{\prime \prime}(\mathbf{\Lambda})$ modulus) of pure PEO gel and nanocomposite gels obtained at (a) $50 \mathrm{kGy}$, (b) $130 \mathrm{kGy}$, (c) $300 \mathrm{kGy}$ from $1.85 \mathrm{wt} \%$ PEO suspensions and (d) from $4 \mathrm{wt} \%$ PEO suspensions at $130 \mathrm{kGy}$ as a function of time and application of different strains (LVR-DR-LVR) at $25^{\circ} \mathrm{C}$. Linear viscoelastic region $(\mathrm{LVR})$ : strain $=0.1 \%$, frequency $=5 \mathrm{~Hz}$; destructive region $(\mathrm{DR})$ : strain $=300 \%$, frequency $=5 \mathrm{~Hz}$. Initial mass percentage of $\mathrm{Fe}^{3+}$ in precursor suspensions is indicated.

Author Contributions: Conceptualization, T.J.; investigation, T.J., I.M.; formal analysis, I.M., N.Š.V., A.P., M.G., G.Š., J.-M.G., G.D.; methodology: T.J.; resources, T.J., M.G., N.Š.V., J.-M.G., G.D.; writing-original draft preparation, T.J., I.M., N.Š.V., M.G.; writing-review and editing, T.J.; supervision of experiments, T.J.; project administration/coordination, T.J.; funding acquisition, T.J. All authors have read and agreed to the published version of the manuscript.

Funding: This work was financially supported by the Croatian Science Foundation under the project UIP-2017-05-7337 "The impact of polymers on the radiolytic synthesis of magnetic nanoparticles" (POLRADNANOP).

Conflicts of Interest: The authors declare no conflict of interest. The funders had no role in the design of the study; in the collection, analyses, or interpretation of data; in the writing of the manuscript, or in the decision to publish the results.

\section{References}

1. Blyakhman, F.A.; Makarova, B.E.; Fadeyev, F.A.; Lugovets, D.V.; Safronov, A.P.; Shabadrov, P.A.; Shklyar, T.F.; Melnikov, G.Y.; Orue, I.; Kurlyandskaya, G.V. The contribution of magnetic nanoparticles to ferrogel biophysical properties. Nanomaterials 2019, 9, 232. [CrossRef] [PubMed]

2. Blyakhman, F.A.; Safronov, A.P.; Zubarev, A.Y.; Shklyar, T.F.; Makeyev, O.G.; Makarova, B.E.; Melekhin, V.V.; Larrañaga, A.; Kurlyandskaya, G.V. Polyacrylamide ferrogels with embedded maghemite nanoparticles for biomedical engineering. Results Phys. 2017, 7, 3624-3633. [CrossRef]

3. Hasan, A.; Morshed, M.; Memic, A.; Hassan, S.; Webster, T.J.; Marei, H.E.-S. Nanoparticles in tissue engineering: Applications, challenges and prospects. Int. J. Nanomed. 2018, 13, 5637-5655. [CrossRef] [PubMed]

4. Cvek, M.; Zahoranova, A.; Mrlik, M.; Sramkova, P.; Minarik, A.; Sedlacik, M. Poly(2-oxazoline)-based magnetic hydrogels: Synthesis, performance and cytotoxicity. Colloid Surf. B Biointerfaces 2020, 190, 110912. [CrossRef]

5. Li, Y.; Huang, G.; Zhang, X.; Li, B.; Chen, Y.; Lu, T.; Lu, T.J.; Xu, F. Magnetic hydrogels and their potential biomedical applications. Adv. Funct. Mater. 2012, 23, 1-13. [CrossRef]

6. Ramanujan, R.V.; Lao, L.L. The mechanical behavior of smart magnet-hydrogel composites. Smart Mater. Struct. 2006, 15, 952-956. [CrossRef]

7. Thoniyot, P.; Tan, M.J.; Karim, A.A.; Young, D.J.; Loh, X.J. Nanoparticle-Hydrogel composites: Concept, design, and applications of these promising, multifunctional materials. Adv. Sci. 2015, 2, 1400010. [CrossRef]

8. Hu, S.; Zhou, Y.; Zhao, Y.; Xu, Y.; Zhang, F.; Gu, N.; Ma, J.; Reynolds, M.A.; Xia, Y.; Xu, H.H.K. Enhanced bone regeneration and visual monitoring via superparamagnetic iron oxide nanoparticle scaffold in rats. J. Tissue Eng. Regen. Med. 2018, 12, e2085-e2098. [CrossRef] [PubMed]

9. Wang, Q.; Chen, B.; Ma, F.; Lin, S.; Cao, M.; Li, Y.; Gu, N. Magnetic iron oxide nanoparticles accelerate osteogenic differentiation of mesenchymal stem cells via modulation of long noncoding RNA INZEB2. Nano Res. 2017, 10, 626-642. [CrossRef]

10. Wang, Q.; Chen, B.; Cao, M.; Sun, J.; Wu, H.; Zhao, P.; Xing, J.; Yang, Y.; Zhang, X.; Ji, M.; et al. Response of MAPK pathway to iron oxide nanoparticles in vitro treatment promotes osteogenic differentiation of hBMSCs. Biomaterials 2016, 86, 11-20. [CrossRef]

11. Henstock, J.R.; Rotherham, M.; Rashidi, H.; Shakesheff, K.M.; El Haj, A.J. Remotely activated mechanotransduction via magnetic nanoparticles promotes mineralization synergistically with bone morphogenetic protein 2: Applications for injectable cell therapy. Stem Cells Transl. Med. 2014, 3, 1363-1374. [CrossRef] [PubMed] 
12. Jurkin, T.; Pucić, I. Irradiation effects in poly(ethylene oxide)/silica nanocomposite films and gels. Polym. Eng. Sci. 2013, 53, 2318-2327. [CrossRef]

13. Marinović-Cincović, M.T.; Radosavljević, A.N.; Krstić, J.I.; Spasojević, J.P.; Bibić, N.M.; Mitrić, N.M.; Kačarević-Popović, Z.M. Physicochemical characteristics of gamma irradiation crosslinked poly(vinyl alcohol)/magnetite ferrogel composite. Hem. Ind. 2014, 68, 743-753. [CrossRef]

14. Eid, M. Preparation and characterization of natural polymers as stabilizer for magnetic nanoparticles by gamma irradiation. J. Polym. Res. 2013, 20, 112. [CrossRef]

15. Jovanović, Ž.; Krklješ, A.; Stojkovska, J.; Tomić, S.; Obradović, B.; Mišković-Stanković, V.; Kačarević-Popović, Z. Synthesis and characterization of silver/poly( $N$-vinyl-2-pyrrolidone) hydrogel nanocomposite obtained by in situ radiolytic method. Radiat. Phys. Chem. 2011, 80, 1208-1215. [CrossRef]

16. Krklješ, A.; Nedeljković, J.M.; Kačarević-Popović, Z.M. Fabrication of Ag-PVA hydrogel nanocomposite by $\gamma$-irradiation. Polym. Bull. 2007, 58, 271-279. [CrossRef]

17. Spasojević, J.; Radosavljević, A.; Krstić, J.; Jovanović, D.; Spasojević, V.; Kalagasidis-Krušić, M.; Kačarević-Popović, Z. Dual responsive antibacterial Ag-poly(N-isopropylacrylamide/itaconic acid) hydrogel nanocomposites synthesized by gamma irradiation. Eur. Polym. J. 2015, 69, 168-185. [CrossRef]

18. Abedini, A.; Daud, A.R.; Hamid, M.A.A.; Othman, N.K. Radiolytic formation of $\mathrm{Fe}_{3} \mathrm{O}_{4}$ nanoparticles: Influence of radiation dose on structure and magnetic properties. PLoS ONE 2014, 9, e90055. [CrossRef]

19. Ekoko, G.B.; Lobo, J.K.-K.; Mvele, O.M.; Muswema, J.L.; Yamambe, J.-F.S.; Mangwala, P.K. Gamma irradiation inducing the synthesis of magnetic $\mathrm{Fe}_{3} \mathrm{O}_{4}$ nanorod particles in alkaline medium. Int. J. Mater. Sci. Appl. 2014, 3, 339-343. [CrossRef]

20. Gotić, M.; Jurkin, T.; Musić, S. Factors that may influence the micro-emulsion synthesis of nanosize magnetite particles. Colloid Polym. Sci. 2007, 285, 793-800. [CrossRef]

21. Gotić, M.; Jurkin, T.; Musić, S. From iron(III) precursor to magnetite and vice versa. Mater. Res. Bull. 2009, 44, 2014-2021. [CrossRef]

22. Jurkin, T.; Zadro, K.; Gotić, M.; Musić, S. Investigation of solid phase upon $\gamma$-irradiation of ferrihydrite-ethanol suspension. Radiat. Phys. Chem. 2011, 80, 792-798. [CrossRef]

23. Jurkin, T.; Štefanić, G.; Dražić, G.; Gotić, M. Synthesis route to $\delta$-FeOOH nanodiscs. Mater. Lett. 2016, 173, 55-59. [CrossRef]

24. Jurkin, T.; Gotić, M.; Štefanić, G.; Pucić, I. Gamma-irradiation synthesis of iron oxide nanoparticles in the presence of PEO, PVP or CTAB. Radiat. Phys. Chem. 2016, 124, 75-83. [CrossRef]

25. Marić, I.; Štefanić, G.; Gotić, M.; Jurkin, T. The impact of dextran sulfate on the radiolytic synthesis of magnetic iron oxide nanoparticles. J. Mol. Struct. 2019, 1183, 126-136. [CrossRef]

26. Sutherland, T.I.; Sparks, C.J.; Joseph, J.M.; Wang, Z.; Whitaker, G.; Sham, T.K.; Wren, J.C. Effect of ferrous ion concentration on the kinetics of radiation-induced iron-oxide nanoparticle formation and growth. Phys. Chem. Chem. Phys. 2017, 19, 695-708. [CrossRef]

27. Wang, S.; Xin, H.; Qian, Y. Preparation of nanocrystalline $\mathrm{Fe}_{3} \mathrm{O}_{4}$ by $\gamma$-ray radiation. Mater. Lett. 1997, 33, 113-116. [CrossRef]

28. Yakabuskie, P.A.; Joseph, J.M.; Keech, P.; Botton, G.A.; Guzonas, D.; Wren, J.C. Iron oxyhydroxide colloid formation by gamma-radiolysis. Phys. Chem. Chem. Phys. 2011, 13, 7198-7206. [CrossRef]

29. Belloni, J.; Mostafavi, M.; Remita, H.; Marignier, J.-L.; Delcourt, M.-O. Radiation-induced synthesis of monoand multi-metallic clusters and nanocolloids. New. J. Chem. 1998, 22, 1239-1255. [CrossRef]

30. Jurkin, T.; Pucić, I. Poly(ethylene oxide) irradiated in the solid state, melt and aqueous solution-A DSC and WAXD study. Radiat. Phys. Chem. 2012, 81, 1303-1308. [CrossRef]

31. Savaş, H.; Güven, O. Gelation, swelling and water vapor permeability behavior of radiation synthesized poly(ethylene oxide) hydrogels. Radiat. Phys. Chem. 2002, 64, 35-40. [CrossRef]

32. Ulanski, P.; Rosiak, J.M.; Zainuddin, A. Pulse radiolysis of poly(ethylene oxide) in aqueous solutions. I. Formation of macroradicals. Radiat. Phys. Chem. 1995, 46, 913-916. [CrossRef]

33. Ulanski, P.; Rosiak, J.M.; Zainuddin, A. Pulse radiolysis of poly(ethylene oxide) in aqueous solutions. II. Decay of macroradicals. Radiat. Phys. Chem. 1995, 46, 917-920. [CrossRef]

34. Jiang, C.Z.; Yang, S.Y.; Gan, N.; Pan, H.C.; Liu, H. A method for determination of $\left[\mathrm{Fe}^{3+}\right] /\left[\mathrm{Fe}^{2+}\right]$ ratio in superparamagnetic iron oxide. J. Magn. Magn. Mater. 2017, 439, 126-134. [CrossRef]

35. Marić, I.; Gotić, M.; Štefanić, G.; Pustak, A.; Jurkin, T. $\gamma$-irradiation generated ferrous ions affect the formation of magnetite and feroxyhyte. Radiat. Phys. Chem. 2020, 170, 108648. [CrossRef] 
36. Marić, I.; Dražić, G.; Štefanić, G.; Zadro, K.; Gotić, M.; Jurkin, T. Characterization of radiolytically synthesized feroxyhyte and magnetite nanoparticles. Mater. Charact. 2020, 159, 110038. [CrossRef]

37. Kamnev, A.A.; Tugarova, A.V. Sample treatment in Mössbauer spectroscopy for protein-related analyses: Nondestructive possibilities to look inside metal-containing biosystems. Talanta 2017, 174, 819-837. [CrossRef]

38. Lopez-Herrera, M.E.; Greneche, J.M.; Varret, F. Analysis of the Mössbauer quadrupole spectra of some amorphous fluorides. Phys. Rev. B 1983, 28, 4944. [CrossRef]

39. Vandenberghe, R.E.; De Grave, E. Application of Mössbauer spectroscopy in Earth Sciences. In Mössbauer Spectroscopy Tutorial Book, 1st ed.; Yoshida, Y., Langouche, G., Eds.; Springer: Berlin, Germany, 2013; pp. 91-186.

40. Gracien, E.B.; Ruimin, Z.; Kanza, L.K.; Lopaka, I. Effects of pH on the morphology of iron oxides synthesized under gamma-irradiation. J. Radioanal. Nucl. Chem. 2006, 270, 473-478. [CrossRef]

41. Spinks, J.W.T.; Woods, R.J. Introduction to Radiation Chemistry, 3rd ed.; John Wiley \& Sons: New York, NY, USA, 1990; p. 262.

42. Spotheim-Maurizot, M.; Mostafavi, M.; Douki, T.; Belloni, J. Radiation Chemistry. From Basics to Application in Material and Life Sciences; EDP Sciences: Les Ulis, France, 2008; pp. 120-121.

43. Swiatla-Wojcik, D. Computation of the effect of $\mathrm{pH}$ on spur chemistry in water radiolysis at elevated temperatures. Nukleonika 2008, 53, S31-S37.

44. Matheson, M.S.; Mamou, A.; Silverman, J.; Rabani, J. Reaction of hydroxyl radicals with polyethylene oxide in aqueous solution. J. Phys. Chem. 1973, 77, 2420-2424. [CrossRef]

45. Dey, G.R.; Remita, H.; Mostafavi, M. Radiolytic reduction of Fe(II) in 2-propanol. Chem. Phys. Lett. 2006, 431, 83-87. [CrossRef]

46. Le Caër, S.; Rotureau, P.; Brunet, F.; Charpentier, T.; Blain, G.; Renault, J.P.; Mialocq, J.-C. Radiolysis of confined water: Hydrogen production at a high dose. Chem. Phys. Chem. 2005, 6, 2585-2596. [CrossRef] [PubMed]

47. Minkova, L.; Stamenova, R.; Tsvetanov, C.; Nedkov, E. Structural studies of radiation-crosslinked poly(ethylene oxide). J. Polym. Sci. Part. B 1989, 27, 621-642. [CrossRef]

48. Wypych, G. Handbook of Fillers, 2nd ed.; ChemTec Publishing: Toronto, ON, Canada, 2000; pp. 485-495, 501-505.

49. Karaoğlu, E.; Kavas, H.; Baykal, A.; Toprak, M.S.; Sözeri, H. Effect of hydrolyzing agents on the properties of poly(ethylene glycol)- $\mathrm{Fe}_{3} \mathrm{O}_{4}$ nanocomposite. Nano Micro Lett. 2011, 3, 79-85. [CrossRef]

50. Mathur, S.; Moudgil, B.M. Adsorption Mechanism of PEO on oxide surfaces. J. Colloid Interface Sci. 1997, 196, 92-98. [CrossRef]

51. Weeber, R.; Kantorovich, S.; Holm, C. Ferrogels crosslinked by magnetic particles: Field-driven deformation and elasticity studied using computer simulations. J. Chem. Phys. 2015, 143, 154901. [CrossRef]

52. Popescu, E.D.; Zaharescu, T.; Gavrilă, G. Insulation properties of degrading LDPE modified with metallic oxides. Optoelectr. Adv. Mater. Rapid Commun. 2011, 5, 1056-1061.

53. Davenas, J.; Stevenson, I.; Celette, N.; Cambon, S.; Gardette, J.L.; Rivaton, A.; Vignoud, L. Stability of polymers under ionizing radiation. The many faces of radiation interaction with polymers. Nucl. Instrum. Methods Phys. Res. Sect. B 2002, 191, 653-661. [CrossRef]

54. Agrawal, S.K.; Sanabria-DeLong, N.; Tew, G.N.; Bhatia, S.R. Nanoparticle-reinforced associative network hydrogels. Langmuir 2008, 24, 13148-13154. [CrossRef]

55. Criado-Gonzalez, M.; Corbella, L.; Senger, B.; Boulmedais, F.; Hernández, R. Photoresponsive nanometer-scale iron alginated hydrogels: A study of gel-sol transition using quartz crystal microbalance. Langmuir 2019, 35, 11397-11405. [CrossRef] [PubMed]

56. Peng, F.; Li, G.; Liu, X.; Wu, S.; Tong, Z. Redox-responsive gel-sol/sol-gel transition in poly(acrylic acid) aqueous solution containing Fe(III) ions swiched by light. J. Am. Chem. Soc. 2008, 130, 16166-16167. [CrossRef] [PubMed]

57. Yang, X.; Zhu, Z.; Chen, X. Thermal and rheological properties of poly(vinyl alcohol) and water-soluble chitosan hydrogels prepared by combination of $\gamma$-ray irradiation and freeze thawing. J. Appl. Polym. Sci. 2008, 109, 3825-3830. [CrossRef] 
58. Van Brederode, R.A.; Rodriguez, F.; Cocks, G.C. Crosslinking poly(ethylene oxide) in dilute solutions by gamma rays. J. Appl. Polym. Sci. 1968, 12, 2097-2104. [CrossRef]

59. Fechine, G.J.M.; Barros, J.A.G.; Alcântara, M.R.; Catalani, L.H. Fluorescence polarization and rheological studies of the poly(N-vinyl-2-pyrrolidone) hydrogels produced by UV radiation. Polymer 2006, 47, 2629-2633. [CrossRef] 